\author{
EISSN:2706-7920 ISSN: 2077- 4435 \\ DOI: $10.36632 / \mathrm{csi} / 2021.10 .3 .31$ \\ Journal homepage: www.curresweb.com \\ Pages: 335-361
}

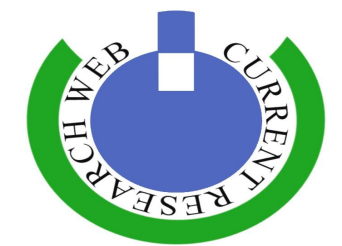

\title{
Geology, Radioactivity and Uranium Potentialities of Some Pegmatite Bodies at Wadi Al Shayilah and West of Gabal Kherm El Asmar Area, North Eastern Desert, Egypt
}

\section{Hossam A. Khamis}

Nuclear Materials Authority, El Kattamyia-Maadi district, Cairo, Egypt

\author{
Received: 10 June $2021 \quad$ Accepted: 08 July $2021 \quad$ Published: 15 July 2021
}

\begin{abstract}
The area around Gabal (G.) Kherm El Asmar is occupied by metavolcanics, Dokhan volcanics as well as different types of younger granite pertaining to the Syenogranites and alkali feldspar granites. These rock types are intruded and traversed by numerous types of dyke swarms and dissected by many fault trends. The metavolcanics are mainly represented mainly by metabasalt, metabasaltic andesite and very rare metamorphosed pyroclastics. The Dokhan volcanics are represented by andesite, dacite as well as acidic and intermediate tuffs and agglomerates. Syenogranites in the area represents a part of G. Urf El Eeir which is coarse grained porphyritic pink granites while alkali feldspar granites represent part of G. Al Shayilah medium grained equigranular reddish pink granite cut and dissected by dyke swarms and traversed by different trends of shear zones. Late magmatic pneumatolytic and hydrothermal stages which products pegmatites, aplites and silica veins are frequently seen in both types of granites but are very spectacular in alkali feldspar granites where large pegmatites veins and pockets are spread in many parts of the intrusion. These pegmatites play a major role in the localization and potentialities of uranium in this sector of younger granites. Most of the radioactive anomalies are connected to the alkali feldspar granites where $U$ and Th have a reasonable concentrated. In the zoned pegmatites, the uranium concentration is seen to be relatively high and reaches up to $250 \mathrm{ppm}$ while the Th recorded $75 \mathrm{ppm}$. The relatively high uranium concentration provides the opportunities for the crystallization of uranium minerals in these pegmatites where both Uranophane and Kasolite are recorded in notable amounts giving the high $\mathrm{U}$ potentialities for these pegmatites.
\end{abstract}

Keywords: Syenogranites, alkali feldspar granites, pegmatite veins and pockets, faults, uranium and thorium, Wadi Al Shayilah.

\section{Introduction}

The granitic rocks, relative to other rock types, are still for long time one of the important targets for uranium exploration and production in the world. In particular, the younger granites of the Eastern Desert of Egypt are considered a major target for the radiometric survey for uranium exploration. Many researches are published either dealing with the geology, geochemistry and petrogenesis of the granitic intrusions or with the related uranium mineralization bearing granites, (radiometrically anomalous granites and fertile granites). These granites are commonly known in the Egyptian literature as Gattarian granite (Hume, 1935), pink and red granites (El Ramly and Akaad, 1960), late and post orogenic plutonites (E1 Shazly, 1964), and G2 to G3 granites (Hussein et al., 1982) as well as (El Gaby, 1975) and younger granites group I of (Rogers and Greenberg, 1981) and Rogers and Greenbergs (1983). A number of petrogenetic models have been suggested for the origin of the calc-alkaline granites in the North Eastern Desert of Egypt including: fractional crystallization of mantle-derived mafic magmas and anatectic melts of various crustal and mantle sources with a crustal contribution (Furnes et al., 1996; Moghazi et al., 1999; El-Sayed et al., 2002; Farahat et al., 2011; Ali et al., 2016). Several authors advocated the lack of sharing of pre-Neoproterozoic crust in 
the formation of calc-alkaline granitoids in the north ANS (Stein and Goldstein, 1996; Stern, 1994 and 2002; Ali et al., 2012).

The North Eastern Desert is characterized by the presence of abundant intrusions of younger granites making this sector of the Eastern Desert as a big cake of granites over which remnants of the older rock types are floating.

The study area is located between $27^{\circ} 18^{\prime}$ to $27^{\circ} 23^{\prime} \mathrm{N}$ and longitudes $33^{\circ} 06^{\prime}$ to $33^{\circ} 14^{\prime} \mathrm{E}$ (Fig. 1) and typically represents the geological suites of the North Eastern Desert where more than $70 \%$ of its area is occupied by different types of younger granites. The area is located at the central portion of the basement complex and is bounded from the east by both G. Abu Harba and G. Kherm El Asmar culminations and from west by the northern part of W. Hammad and from north by Abu Marwa granitic ridge and from south by G. El Hourus granites. The area is traversed by three main wadies through which the radiometric survey was conducted to the exposed rocks of the study area namely: W. Al Shayilah, W. Abu Harba and W. Umm Asmar as appear in the Landsat image in (Fig.2).

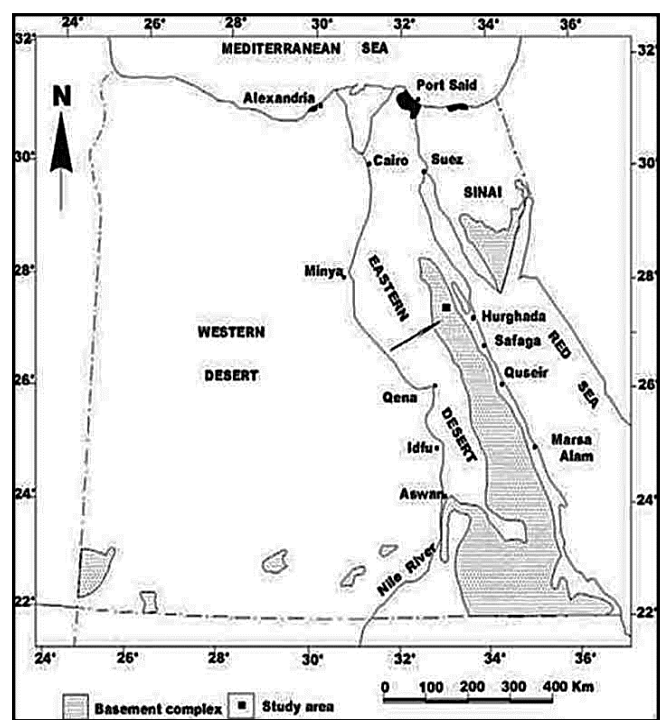

Fig. 1: Location map of the study area in North Eastern Desert of Egypt.

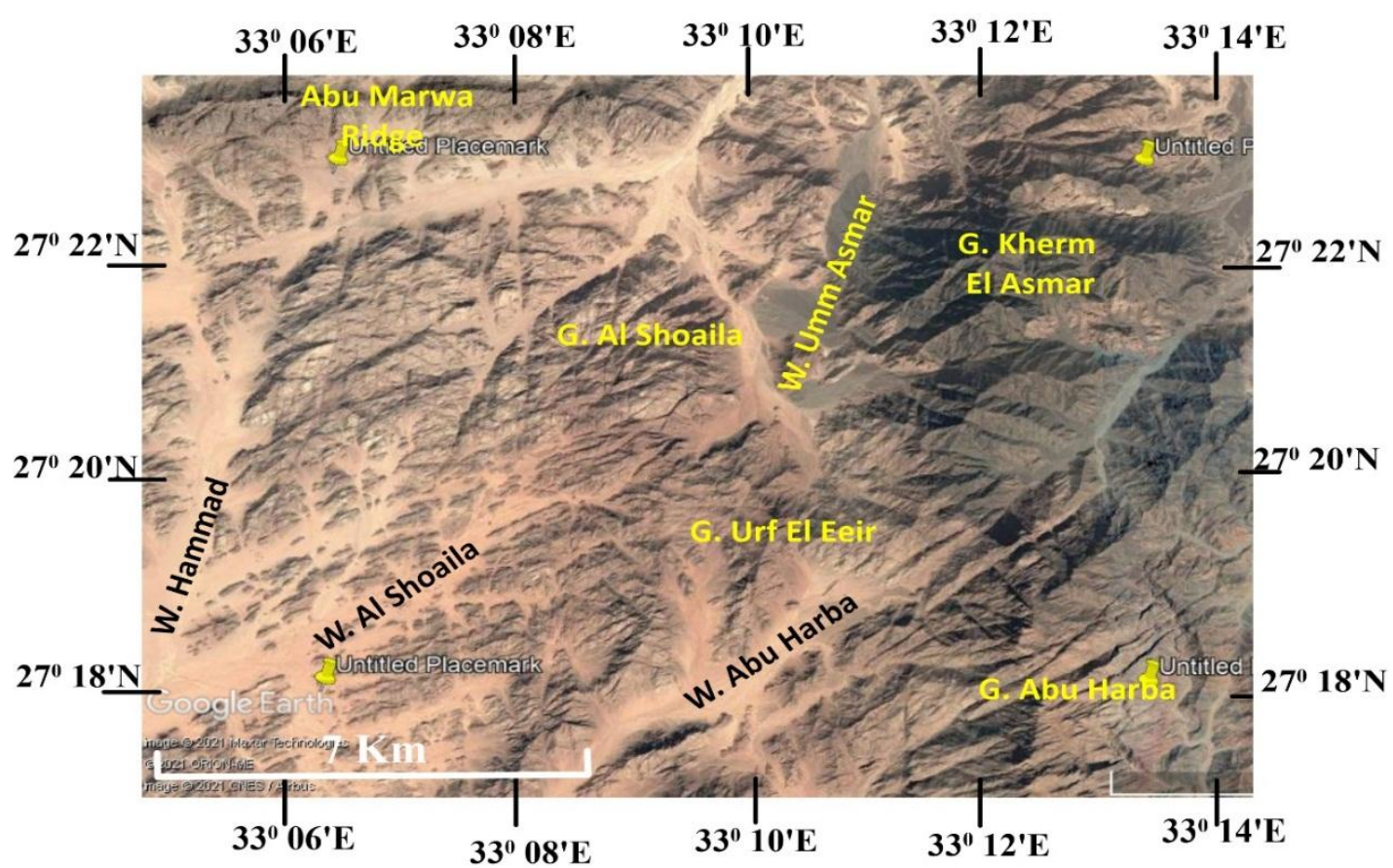

Fig. 2: Landsat image of the study area 


\section{Geological Setting}

\section{A) Field Geological Setting}

The study area is covered by different rock types as demonstrated in the geological map (Fig.3). These rocks are arranged from older to the younger as follow depending on the mutual field relation between then:

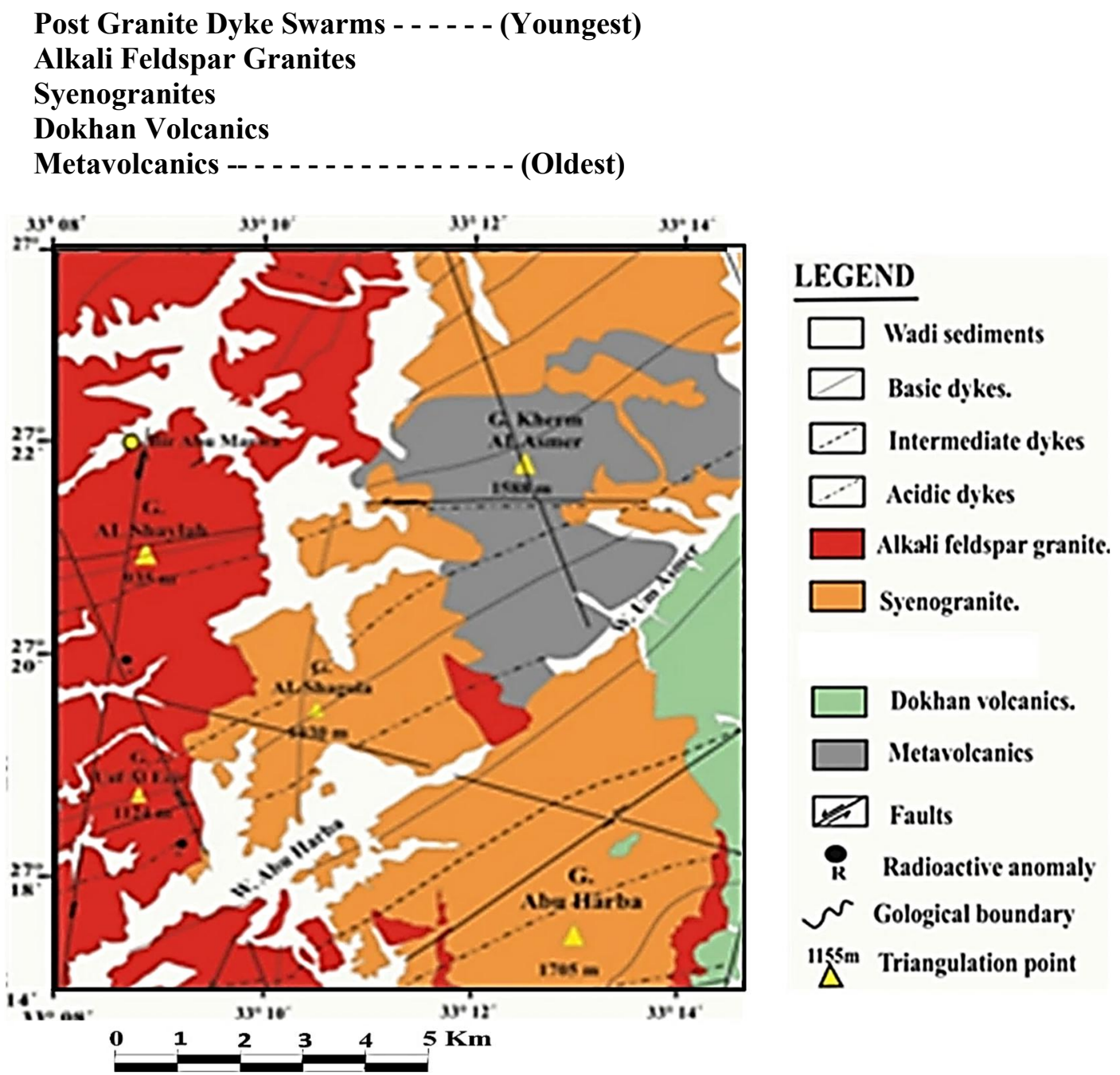

Fig. 3: Geological map of Gabal Al Shayilah - Kherm El Asmar area, NED, Egypt.

The metavolcanics are well exposed at G. Kherm El Asmar and are related to the Island Arc volcanic type (Khaled, 2021), (Abdel Hamid, (2013) and (Roz, 2001). These volcanics constitute the main bulk of G. Kherm El Asmar and are present as huge roof-pendant of dark black colour, with steep and rough topography, floated over the syenogranites of the northern part of G. Abu Harba (Fig.4a \&b). They are also slided and down faulted to occupy some parts of W. Umm Asmar and W. Al Shayilah. Kherm El Asmar metavolcanics are mainly represented by lava flows of metabasalt, metadolerite, metabasaltic andesite and meta-andesite with very rare or no metapyroclastics. They are invaded by intensive quartz and aplite veins near their contact with the younger granite (Fig.4c \&d). The metavolcanics show slightly developed $\mathrm{S}_{0} / / \mathrm{S}_{1}$ foliations but layering is remarkably seen in some places where successive lava flow of metabasalt and meta-andesite are interlayered (Fig. 4b). 

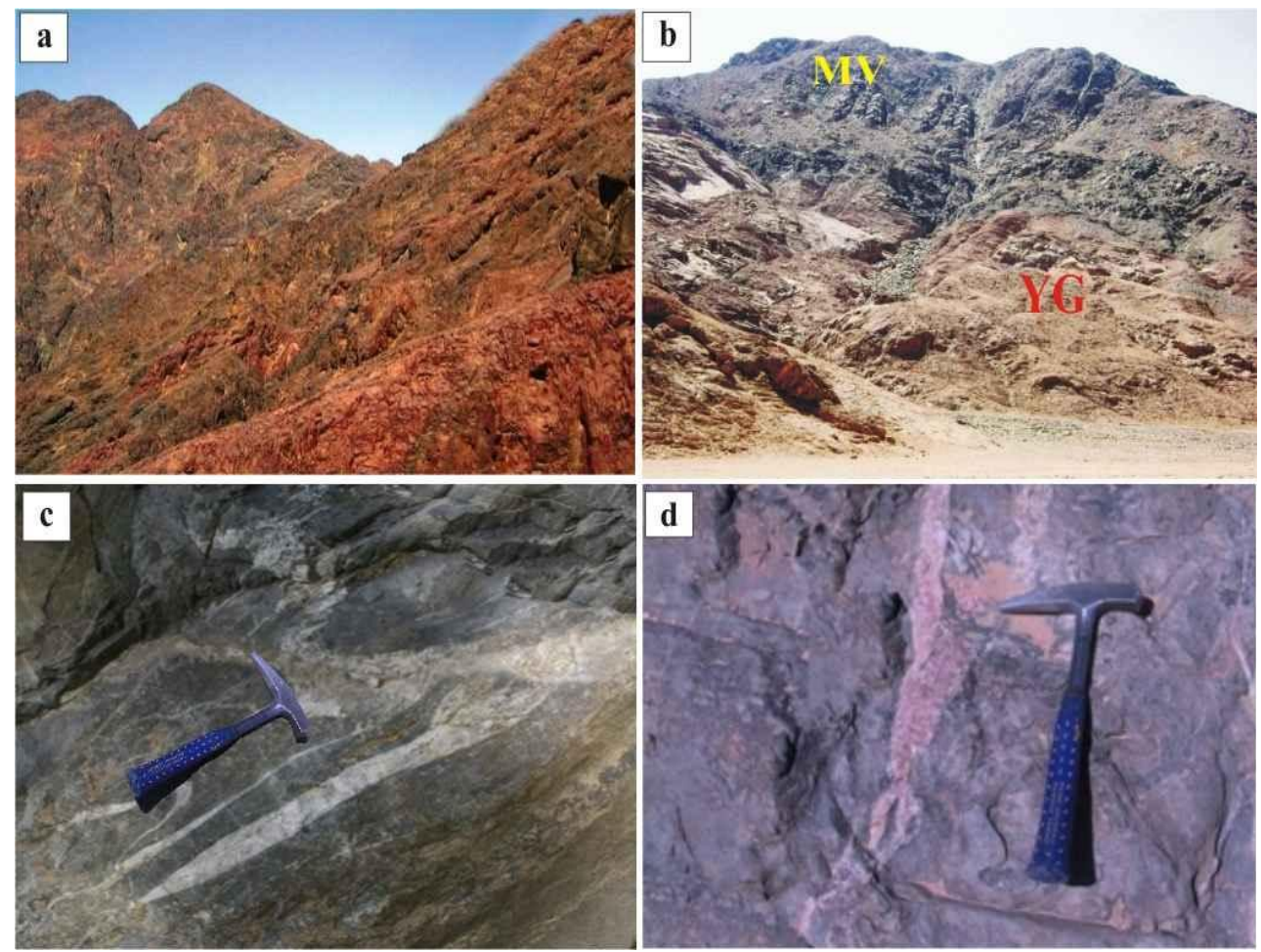

Fig. 4: Field photographs of the metavolcanics in the study area.

4-a: The metavolcanics forming high ridges with steep slopes and rough topography, G. Kherm Al Asmer; looking North.

4-b: The younger granites (YG) intrude the metavolcanics (MV) with sharp and irregular intrusive contact, G. Kherm Al Asmer; looking North.

4-C: Close up view showing quartz vein invading the metavolcanics, W. Umm Asmar, looking NE.

4-d: Close up view showing aplite veins cut through the metavolcanics near the contact with the syenogranite, G. Kherm Al Asmer; looking NE.

Petrographically, these volcanics show clear signs of regional metamorphism to the epidoteamphibolite facies where abundant actinolite and tremolite minerals are seen forming the slightly developed foliations in the metabasalts. These volcanics are represented by three rock types namely: metabasalt, metadolerite and meta-andesite according to the mineral constituents specially the type of plagioclase.

The metabasalts show tabular crystals of anorthitic plagioclase (Fig.5a) with flackes of pyroxenes, tremolite in addition to iron oxides as opaque minerals. They show a well distinctive blasto-amygdalloidal texture (Fig.5) and sometimes porphyritic texture when plagioclase has a two generation of crystallization. The metabasalts have fibrous crystals of tremolite-actinolite as a metamorphic minerals in addition to epidote which indicate the metamorphic facies of these metavolcanics (Fig.5c). Blastodoleritic texture is very characteristic to the metadolerite of these volcanics where triangles made by plagioclase laths enclose altered pyroxenes and tremolite in the middle indicating a relict texture inherited in these dolerites (Fig. 5d).

The intermediate varieties of those metamorphosed volcanics are represented by andesite and andesite porphyry where the andesite is composed of nearly equal sizes, interlocked crystals of plagioclase which has intermediate (andesine) composition as well as simply twinned brownish crystals of hornblende (oxy-hornblende) (Fig. 5e). While the andesite porphyry shows two generations of plagioclase and hornblende crystallization where large laths of plagioclase are surrounded by a groundmass of plagioclase, sericite and epidote (Fig. $.5 \mathrm{f}$ ). 

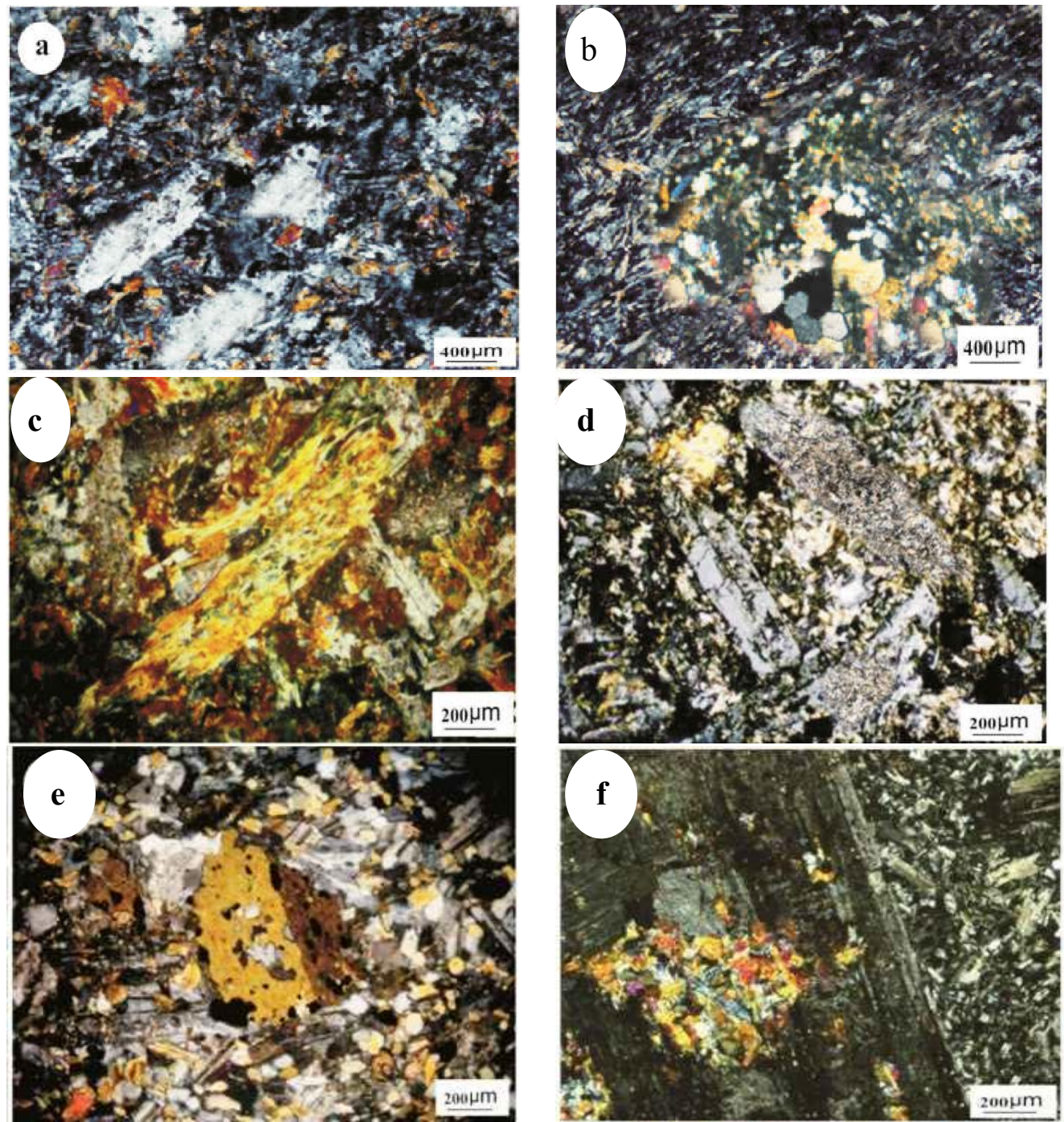

Fig. 5: Photomicrographs of metavolcanics.

5-a: Tabular crystals of plagioclase in the metabasalt, C.N.

5-b: Epidote with high interference colors and six-sided quartz crystals within amygdales in metabasalt, C.N.

5-c: Fibrous tremolite-actinolite as alteration product of pyroxene and facies indicator, C.N.

5-d: Plagioclase phenoblasts forming blastodoleritic texture, highly altered to saussurite in the metadolerites, C.N.

5-e: Phenocrysts of oxy-hornblende with simple twining surrounded by plagioclase laths, meta-andesite, C.N. 5-f: Blasto-porphyritic crystal of plagioclase altered to epidote in its core, meta-andesite porphyry, C.N.

The Dokhan volcanics in the area are well exposed at the eastern part of G. Kherm El Asmar and represent a large part of it. These types of volcanics represent a within plate rift-related fissure eruptions at the late stages of the Pan-African Orogeny (Moghazi, 1994; El Kholy, 1999, El Sayed et al., 2004, Eliwa, 2000, and 2014). These volcanics form relatively high ridges with very steep topographic scenery (Fig.6a). These rocks are invaded and intruded by the syenogranites of G. Abu Harba as dykes, off-shoots, tongues and veins of different sizes (Fig. 6b). Dokhan volcanics are mainly represented by andesite, andesite porphyry, dacite, rhyodacite and rhyolites as lava flows where the more basic varieties such as basaltic andesite are very rare and never repeated in the volcanics sequence. These volcanics also include a large amount of pyroclastics such as agglomerates, lapilli, lapilli-tuffs and tuffs of intermediate to acidic composition. Near the surrounding granites, they are seen cut and invaded by numerous quartz and aplite veins (Fig. 6c). 


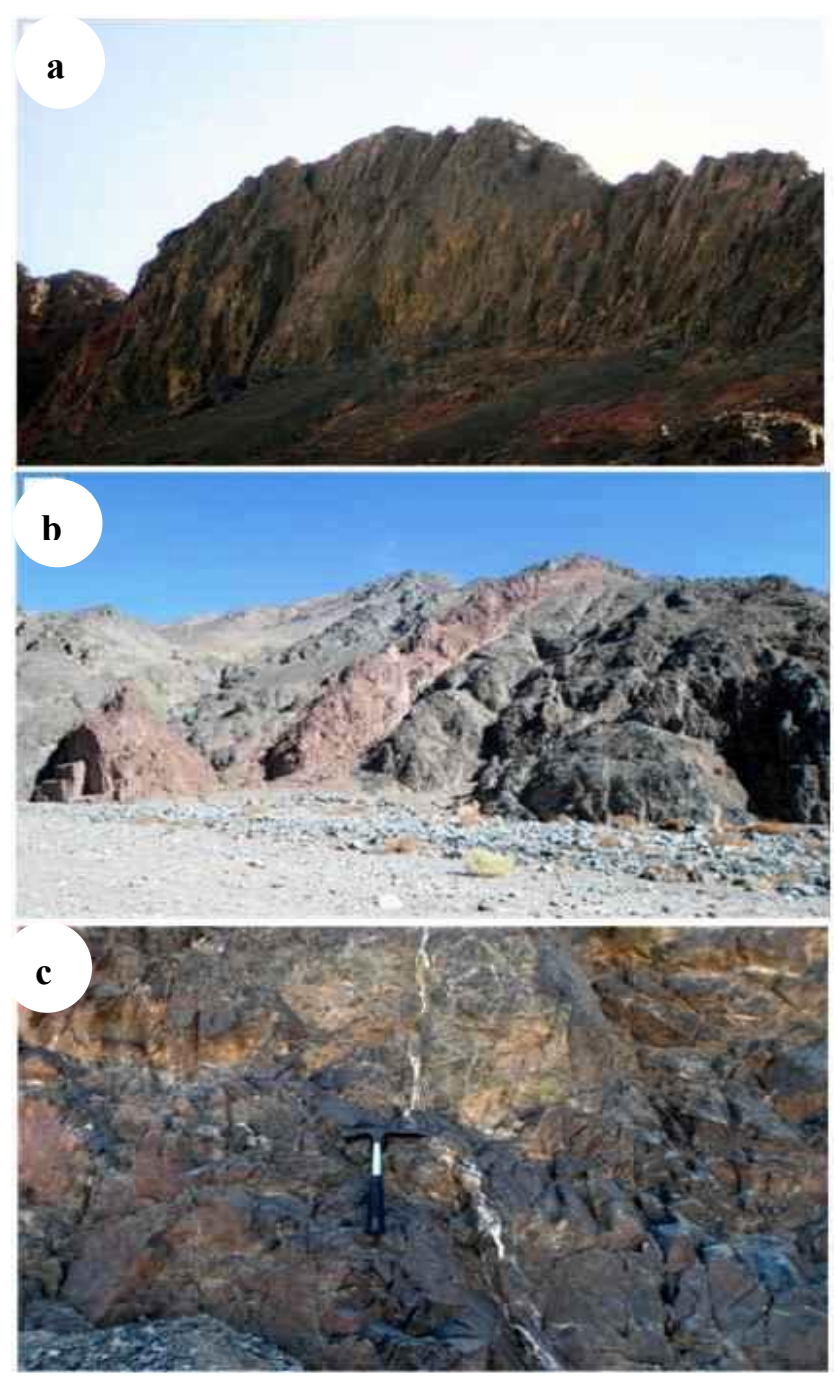

Fig. 6: Field photographs of Dokhan Volcanics in the studied area.

6-a: Vertical columnar jointing of the Dokhan Volcanics, W. Um Asmer; looking S.

6-b: An arm of the syenogranites cut through the Dokhan Volcanics, W. Um Asmer; looking NE.

6-c: Quartz vein invade the Dokhan Volcanics, southeast of G. Kherm El Asmer; looking S.

Petrographically, the Dokhan volcanics are the most abundant rock type in the area where they have large number of varieties either in their lava flows or their pyroclastics. It can be differentiated into basaltic andesite, andesite, dacite and rhyolites as lava flows. The pyroclastics are represented by intermediate agglomerates, lapilli, lapilli-tuffs and ignimbrite.

The basaltic andesite is the rare variety in Dokhan volcanics. It is composed of pyroxene and amphibole as well as plagioclase porphyritic crystal embedded in fine grained groundmass (Figs. $7 \mathrm{a}$ and b). The plagioclase is, generally, altered to sericite and occasionally shows flow texture.

Andesite is the main and most abundant type of lava flows. It commonly exhibits glomero-porphyritic and porphyritic texture and well distinctive flow texture. Zoned plagioclase is the main plagioclase type present and oxy hornblende of brownish yellow colors area abundantly seen (Figs. 7c and d).

Ranks second in abundance is the dacite and rhyodacite where both show porphyritic plagioclase and quartz crystal embedded in a groundmass of finer plagioclase, quartz and hornblende and biotite. (Fig.7e). The plagioclase is of the zoning type and the groundmass is very fine grained and sometimes have a glassy nature (Fig. 7f).

The rhyolites show the typical textures of recrystallization where the glassy rhyolites show a spherulitic texture composed of cryptocrystalline quartz and feldspars (Fig. $7 \mathrm{~g}$ ). The presence of kfeldspar in the form of the simply twinned sanidine indicates the high temperature associated with the crystallization of these acidic lavas (Fig. 7h). 
Curr. Sci. Int., 10(3): 335 - 361, 2021
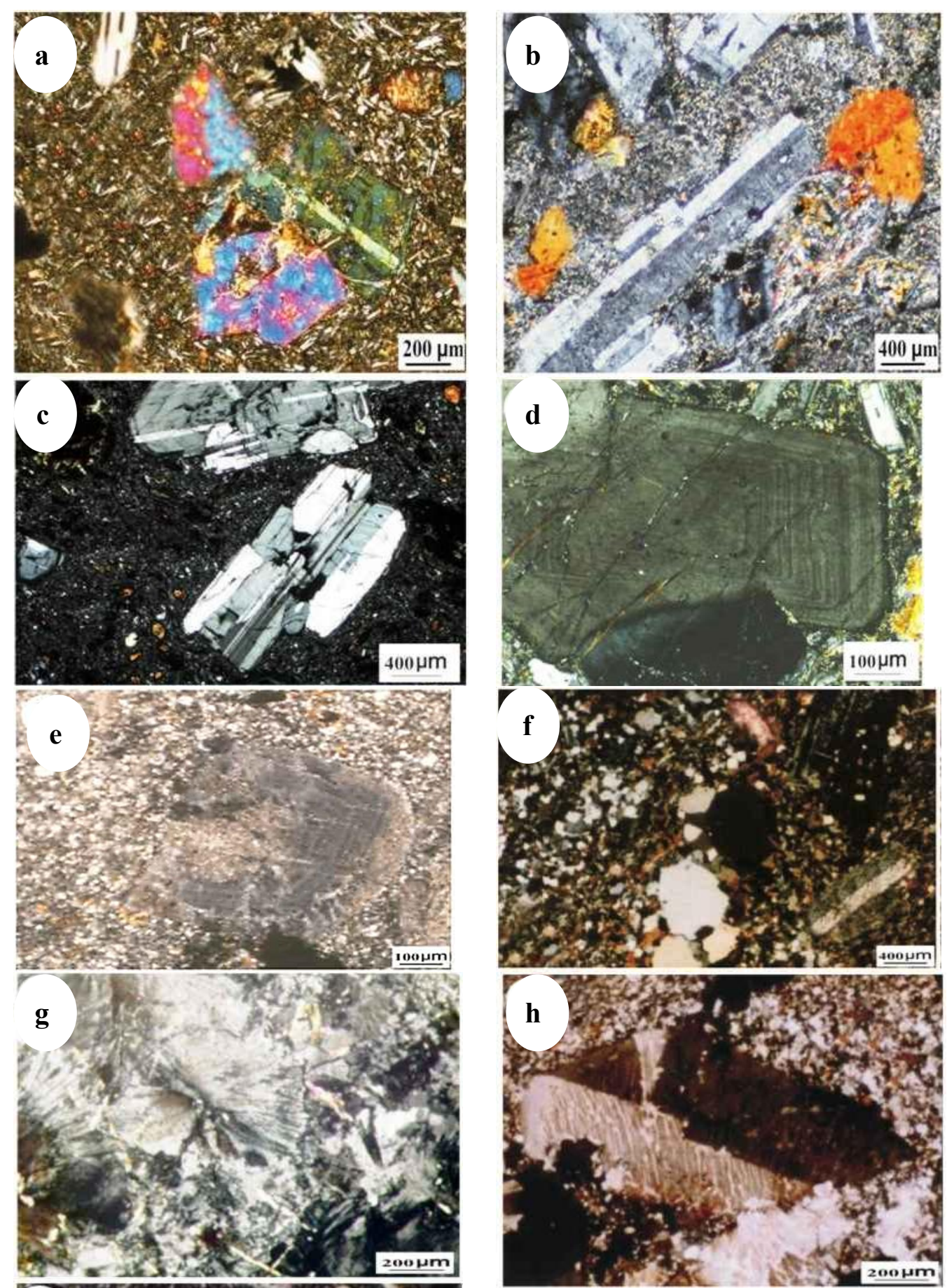

Fig. 7: Photomicrographs of the Dokhan volcanics lava flows.

7-a: Plagioclase and pyroxene phenocrysts showing glomero-porphyritic texture and embedded in fine-grained groundmass, C.N.

7-b: Twinned plagioclase phenocrysts, with small hornblende phenocryst, showing preferred orientation (flow texture), C.N.

7-c: Plagioclase phenocryst showing lamellar twinning in andesite, C.N.

7-d: Plagioclase phenocryst, showing oscillatory zoning in andesite, C.N.

7-e: Quartz, plagioclase and biotite phenocrysts embedded in fine-grained groundmass of the same composition in dacite, C.N.

7-f: Plagioclase phenocryst showing oscillatory zoning in dacite, C.N.

7-g: Spherulitic texture composed of cryptocrystalline quartz and feldspars, C.N.

7-h: Sanidine phenocryst showing simple twinning, C.N. 
The pyroclastics are represented by agglomerates, lapillis, lapilli-tuffs, ignimbrites and banded tuffs according to their grain size variation, the ratio and type of fragments components and the matrix enclosing them (Schmid, 1981). The composition of these pyroclastics is conformable with their lava sources and is ranging from intermediate to acidic composition.

Agglomerates are composed of andesitic and dacitic, angular to subrounded, rock fragments (> $5 \mathrm{~mm}$ diameter) which are cemented and welded by a thin veneer of tuffaceous matrix (Fig.8a).

The lapillis are composed of a sand size angular fragments of plagioclase, k-feldspar, quartz and biotite in addition to few rock fragments of dacitic composition giving rise to lithic-crystal lapilli (Fig. $8 b)$.

Ignimbrites constitute a texturally distinctive welded tuffs where angular crystal fragments of quartz and plagioclase are seen deforming the laminations of the underlying tuffs. A well flow banding characters is demonstrated in these ignimbrites indicating the moistening nature of these tuffs during their formation (Fig. 8c and d).

The tuffs are varying in their composition but mainly the acidic type is more abundant where fragments of orthoclase, plagioclase and quartz are the main constituents. They sometimes exhibit abundant crystal fragments giving rise to crystal tuffs (Fig. 8e) while the banded varieties with rhythmic banding of coarse and fine tuffs is clearly seen (Fig. 8f).
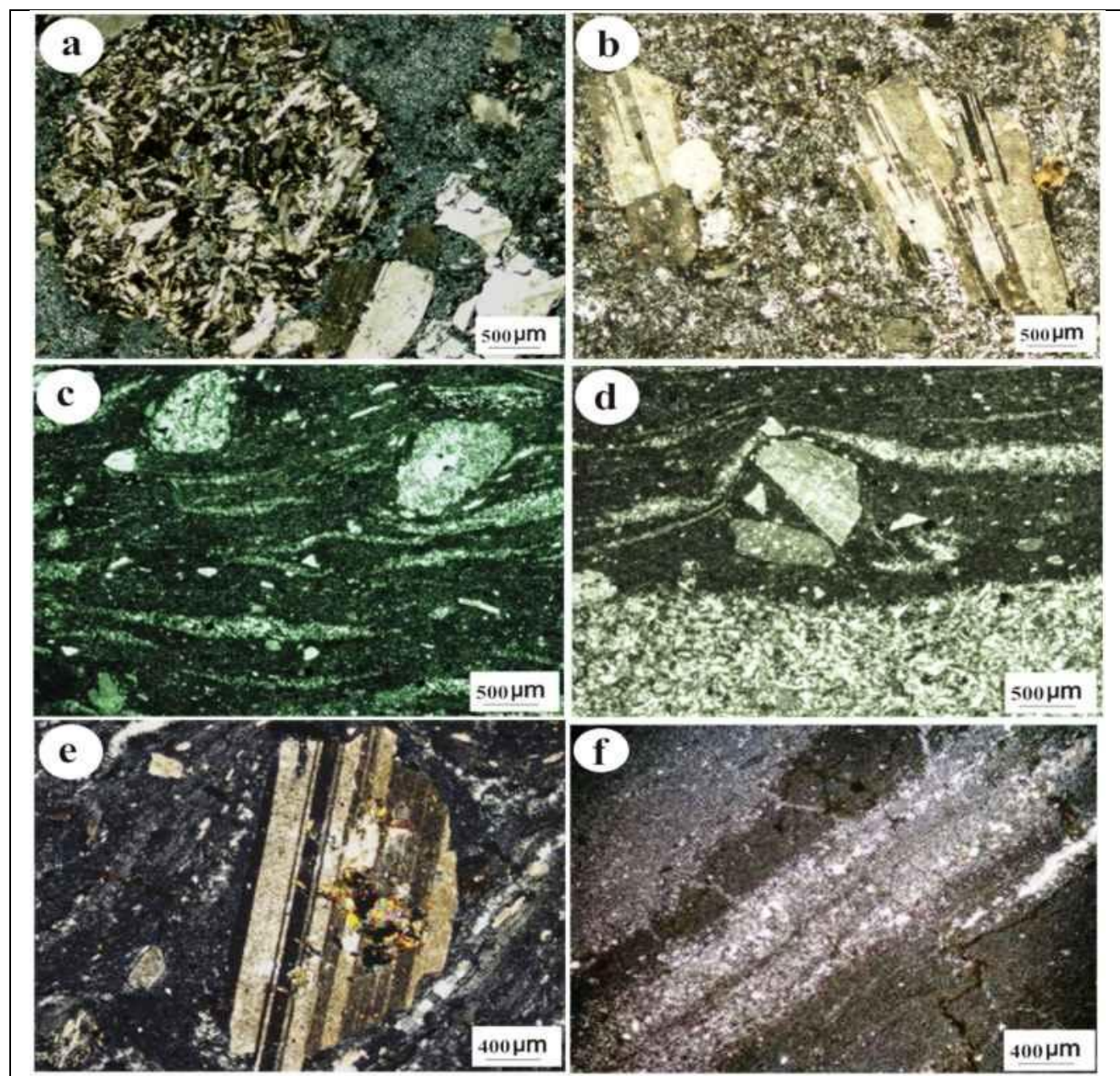

Fig.8: Photomicrographs of the pyroclastics of Dokhan volcanics.

8-a: Andesite and dacite subangular fragments compacted together in intermediate agglomerates C.N.

8-b: Plagioclase crystal and crystal fragments with variable sizes embedded in fine-grained matrix in the crystal lapilli tuff, C.N.

8-c: Fiamme, lithic and crystal fragments set in glassy groundmass in ignimbrites, C.N.

8-d: Curving and deformation of the laminations around the crystal fragments in ignimbrites, C.N.

8-e: Plagioclase fragments altered to epidote in crystal tuffs, C.N.

8-f: Alternating laminae of variable grain size and colors in banded andesitic tuffs, C.N. 
The syenogranites constitute a widely distributed rock type in the study area (Fig. 3). These granites constitute most of G. Abu Harba granitic mass, G. Al Shagola and the granitic base of G. Kherm El Asmar and cover vast areas along W. Abu Harba and W. Umm Asmar.

The syenogranites intrude the Dokhan volcanics with sharp intrusive contacts along W. Umm Asmar to the west of the study area (Fig.9a).
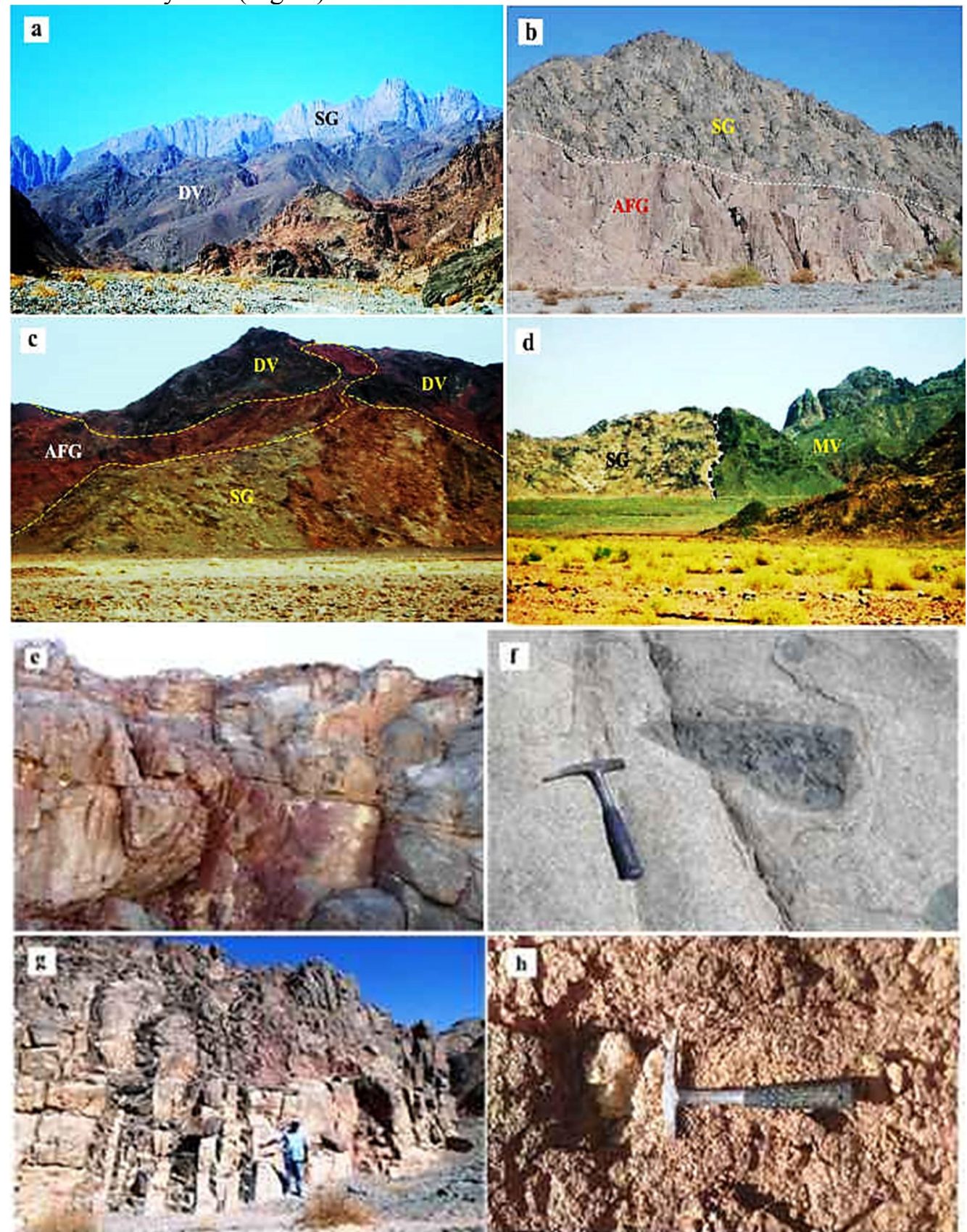

Fig. 9: Field photographs of syenogranites in the studied area.

9-a: The syenogranite (SG) forms the high serrated peaks of G. Abu Harba intruding the Dokhan Volcanics (DV), western part of W. Umm Asmar, looking SW.

9-b: Gradational contact between the syenogranite (SG) and the alkali feldspar granite (AFG), G. Urf El Eeir, looking NW.

9-c: The syenogranite (SG) and the alkali feldspar granite (AFG) intrude the Dokhan Volcanics (DV), south of the study area; looking SE.

9-d: Sharp contact between the syenogranite (SG) and the metavolcanics (MV), G. Kherm Al Asmer, looking $\mathrm{N}$.

9-e: The syenogranite showing exfoliation and joints stained with red hematitic solution, W. Um Asmar, looking SW. 
9-f: Close up view showing the syenogranites containing xenoliths of different size of Dokhan Volcanics, G. Al Shagola; looking NE.

9-g: Closely spaced parallelbasic dykes in the syenogranite, eastern part of the area, looking N.

9-h: Close up view showing pegmatite pocket in the syenogranite, west of the study area looking NE.

The granites also intrude and cut as veins and dykes the metavolcanics of G. Kherm El Asmar (Fig. 9d) where as the syenogranite itself is intruded by the younger alkali feldspar granites in more or less gradational contact and in some places with sharp contact when the later invade the fractures and joint sets of the earlier (Figs. 9b and c).

The syenogranites are well jointed and fractured and carry sharp angular xenoliths of the older rocks (Fig. 9e and f). These granites are intruded by post granite dyke swarms of acidic and basic compositions (Fig. 9g) and are characterized by the presence of small pockets of pegmatites near their contacts with other rock types (Fig. 9h).

Syenogranites are generally equigranular (sometimes porphyritic), massive, and medium to coarse grained rock. they exhibit hypidiomorphic textures. They are mainly composed of potash feldspar, quartz, plagioclase and biotite as essential minerals. The accessory minerals include zircon, sphene, muscovite, apatite and iron oxides, while epidote and chlorite are secondary minerals. Due to the presence of both orthoclase perthites and plagioclase the syenogranites can be classified as subsolvus granite (Tuttle and Bowen, 1958).

Microscopically, the granite is very characterized by the presence of patchy, string, flame and cross hatched twinned k-feldspar (Figs. 10a to 10f) in addition to the presence of mammillary twinned oligoclase as a separate mineral phase. Biotite flackes are seen enclosing abundant zircon, sphene and apatite.

The alkali feldspar granites are the second rock type in abundance where these granites occupy the western sector of the mapped area. They form the main mass of G. El Shayilah and G. Urf El Eeir (Fig. 11a) and covering a wide area along W. Abu Harba, W. El Shayilah and are squeezed between the syenogranites and the metavolcanics at the promontories of G. Kherm El Asmar (Fig. 3).

This type of granite is considered the youngest in the mapped area. It forms sharp serrated peaks with steep and rough topographic scenery (Fig.11d) and shows a well blocky jointed pattern (Fig. 11b). These granites are seen cut and intrude all the above-mentioned rock types with sharp intrusive contacts (Fig. 11e and f). The alkali feldspar granite is cut by numerous milky quartz veins and shows sometimes a strong iron oxide alteration turning the granite color to reddish brown (Fig. 11c). The alkali feldspar granites are frequently seen cut and intruded by acidic and basic dyke swarms (Fig. 11f).

Petrographically, the alkali feldspar granites are generally equigranular, medium to coarsegrained with hypidiomorphic texture and whitish pink to pinkish red in color. They consist mainly of potash feldspar, quartz, subordinate plagioclase, and few biotite as essential minerals. The main accessory minerals are opaque minerals, sphene, zircon and apatite, whereas the secondary minerals are chlorite, epidote, sericite, and muscovite. The mafic minerals are scarce giving rise to the leucogranite type.

Potash feldspar is the main constituent and is represented by orthoclase and microcline perthites. Orthoclase perthite occurs as large subhedral tabular crystals and commonly shows simple twinning (Fig.12a). The crystals are generally of string, patchy and/or flame - like types and are corroded by quartz (Figs. 12b to f)

Quartz forms large subhedral as well as anhedral fine-grained crystals filling up the irregular interspaces among the earlier crystallized minerals. Biotite is the only mafic mineral presents in minor amounts. It occurs as subhedral long and broad flakes and shows moderate pleochroism. Intergrowths are very common where the quartz form micrographic texture with perthite (Fig. 12d) in addition to the perthite itself as an intergrowth between the feldspar and the plagioclase.

Biotite, if present, is seen as small flackes squeezed between the quartz and felspar and showing a strong pleochroism. It encloses abundant zircon and sphene in their crystals and sometimes surrounded by abundant opaques of iron oxide (Fig. 12b). 


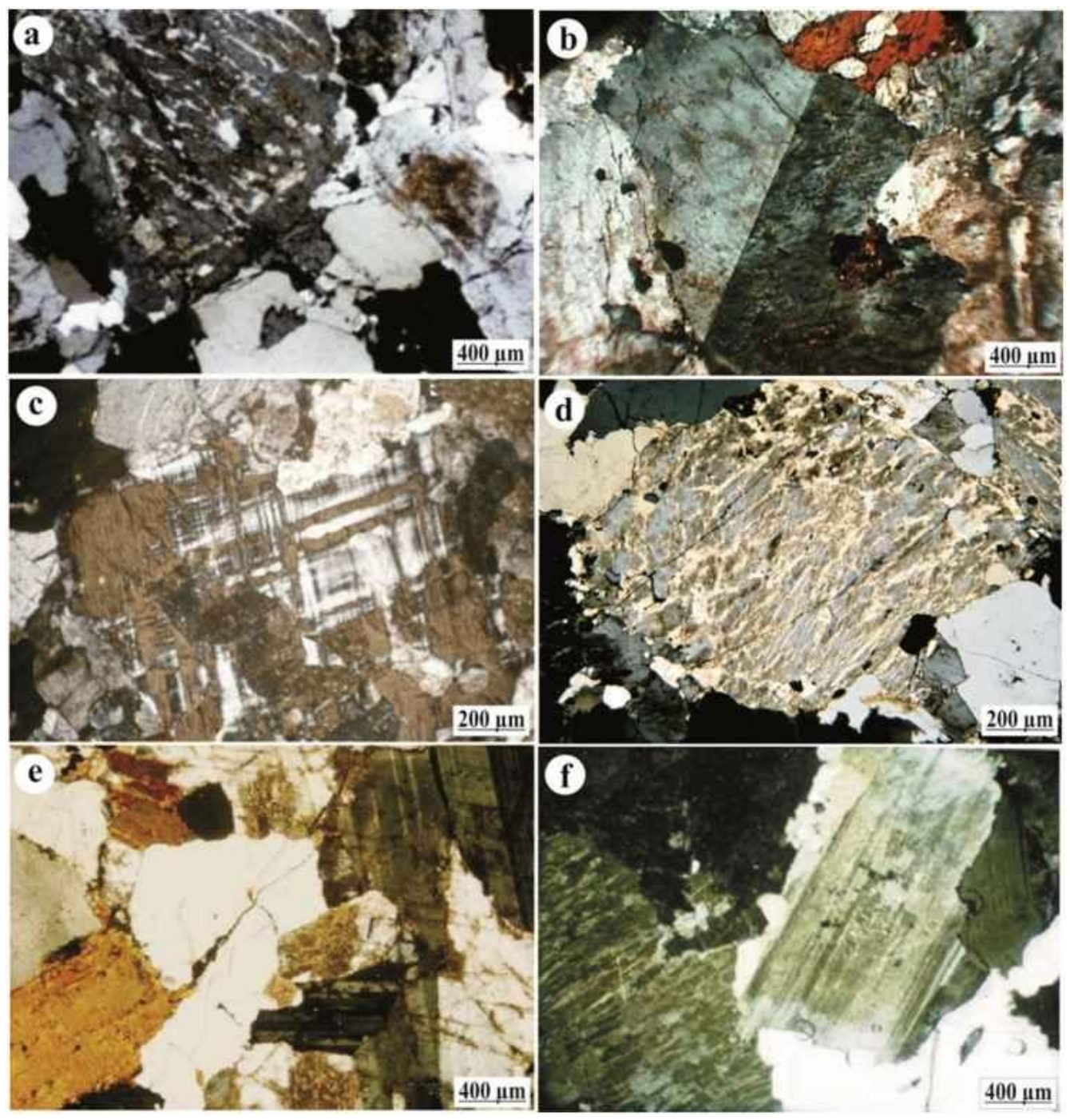

Fig. 10: Photomicrographs of syenogranites.

10-a: Patchy type orthoclase perthite corroded by quartz, C.N.

10-b: Orthoclase perthite showing simple twinning, C.N.

10-c: Anhedral crystal of patchy microcline perthite showing cross- hatching twinning, C.N.

10-d: Flame-type orthoclase perthite enclosing poikilitically quartz crystal, C.N.

10-e: Anhedral quartz crystal corroding orthoclase perthite, plagioclase and biotite, C.N.

10-f: Slightly altered plagioclase with characteristic lamellar twinning and corroded by other fresh plagioclase, quartz and perthite, C.N. 


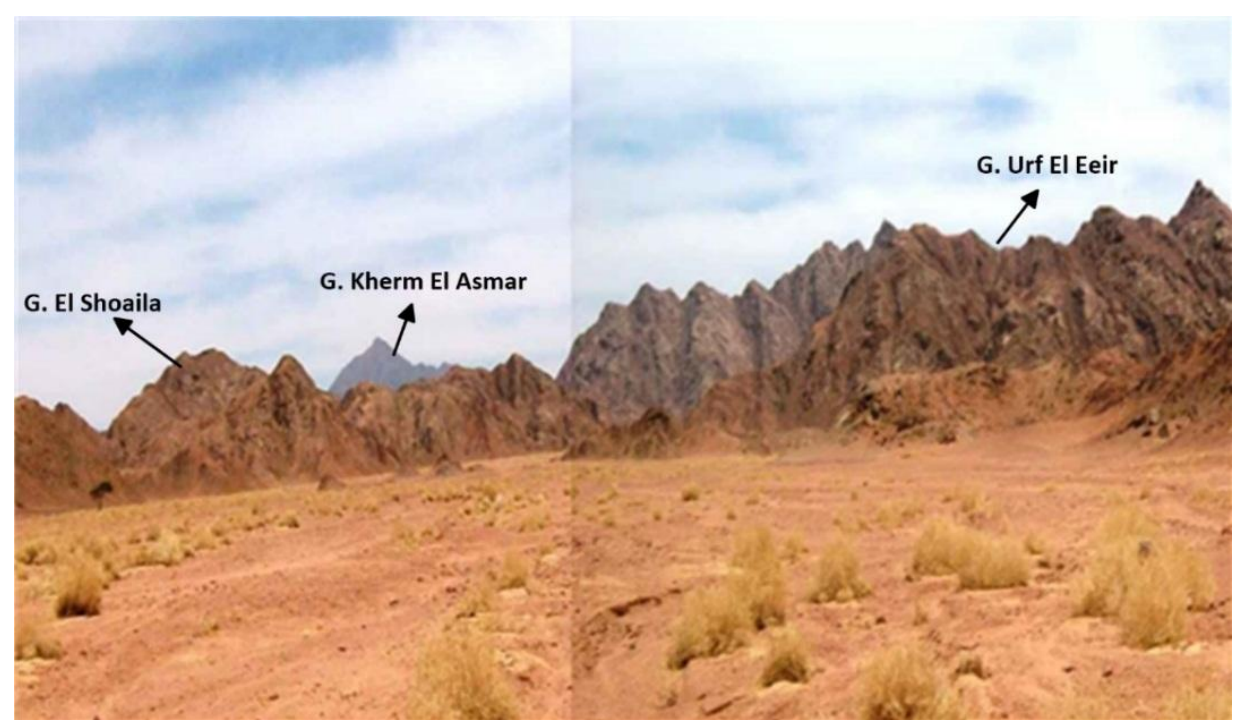

Fig. 11-a: Panoramic View of the alkali feldspar granites of G. Al Shayilah and G. Urf El Eeir along W. Al Shayilah, Looking NNE.
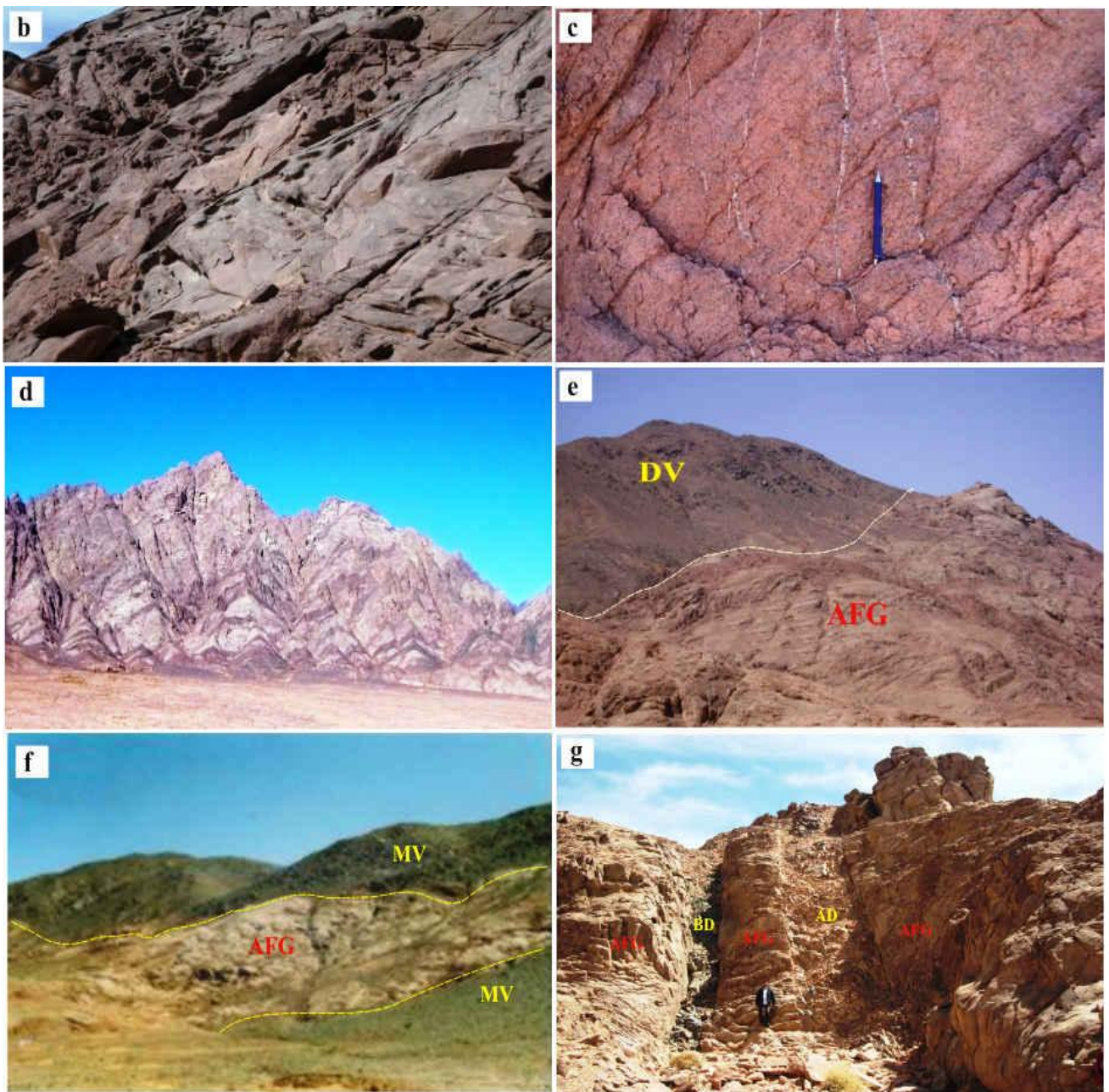

Cont. Fig. 11: Field photographs of alkali feldspar granites in the studied area.

11-b: The alkali feldspar granite showing joints with tuffoni weathering, G. Al Shaylah; looking N.

11-c: Close up view showing quartz viens filling the microfractures in the alkali feldspar granite, G. Al Shaylah; looking $\mathrm{N}$.

11-d: Dyke swarms trending NE-SW cutting through the alkali feldspar granite, G. Al Hurus; looking SE.

11-e: The alkali feldspar granites (AFG) intrude the Dokhan Volcanics (DV) with sharp intrusive contact, G. Urf El Eeir, looking S. 
11-f: The alkali feldspar granites intrude the metavolcanics at the foot slope of G. Kherm El Asmar, looking NE. 11-g: Acidic (AD) and basic dykes (BD) cut through the alkali feldspar granite (AFG), G. Al Shayilah; looking E.

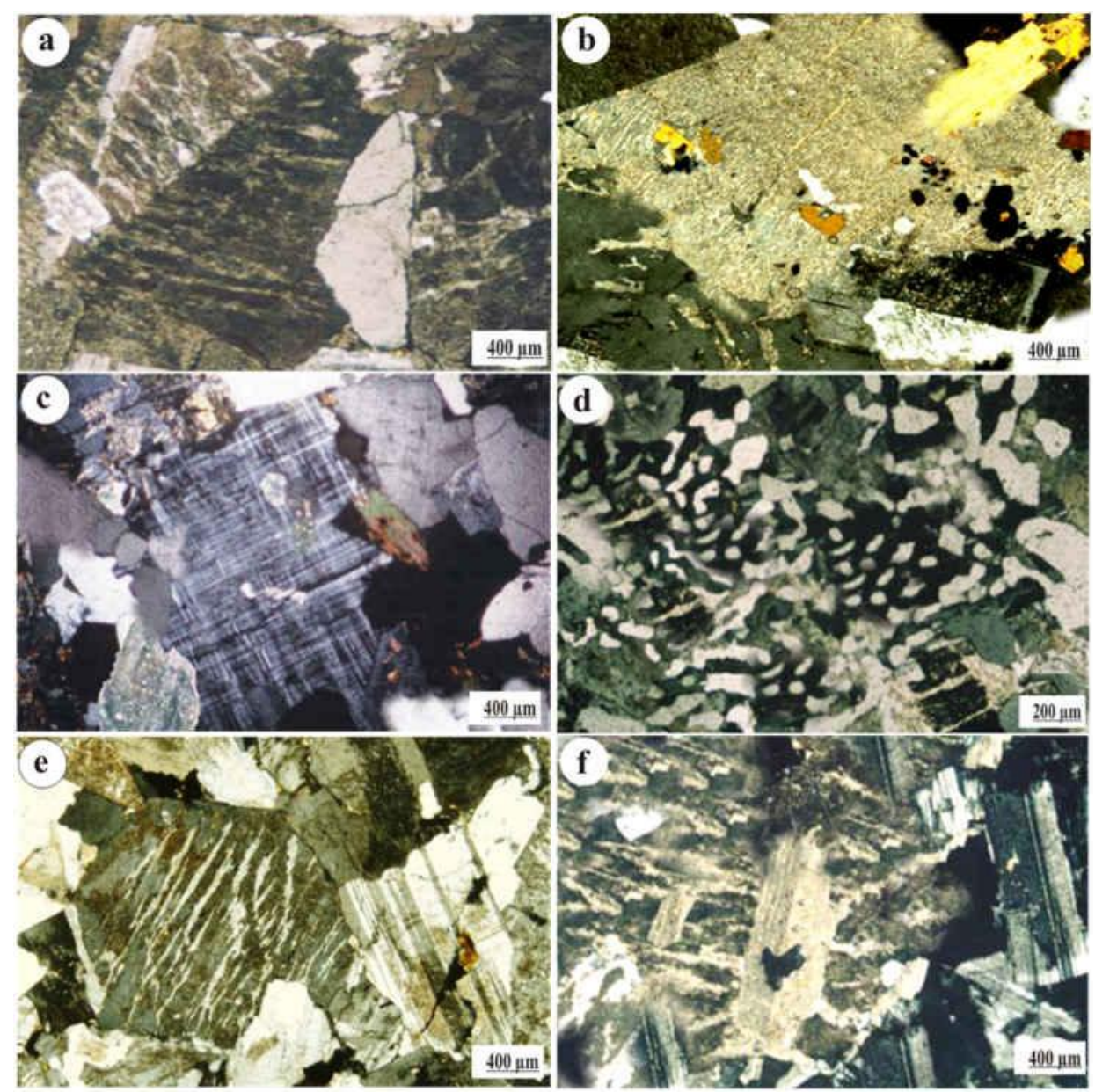

Fig. 12: Photomicrographs of alkali feldspar granites.

12-a: Simply twinned orthoclase perthite showing patchy perthitic intergrowth type and corroded by quartz, C.N.

12-b: String type orthoclase perthite corroded by quartz and enclosing biotite flakes and iron oxide, C.N.

12-c: Anhedral crystal of microcline perthite showing cross-hatch twinning, C.N.

12-d: Micro graphic-like intergrowth texture between fine quartz and perthite, C.N.

12-e: Plagioclase crystal showing lamellar twinning and corroded by quartz and perthite, C.N.

12-f: Large perthite crystal enclosing fine albite laths partially altered to sericite and has fine albite along their outer peripheries, C.N.

\section{Major fault trends in the area}

Statistical treatment of the measured faults revealed that the NE-SW, ENE-WSW, E-W and N-S are the most predominant fault trends (Fig. 13). According the mutual field relation between the fault trends it is found that the E-W to ENE-WSW and NW-SE trending faults are the oldest ones, since they were cut and dislocated by the (younger) N-S, NNE-SSW and NNW-SSE as well as NE-SW trending faults. This study demonstrates that NE-SW, NNW-SSE and N-S trends represent sinistral strike-slip faults. These trends are later on rejuvenated as normal tensional faults and their intersections have played critical roles in distribution of the uranium mineralization. 
(a)

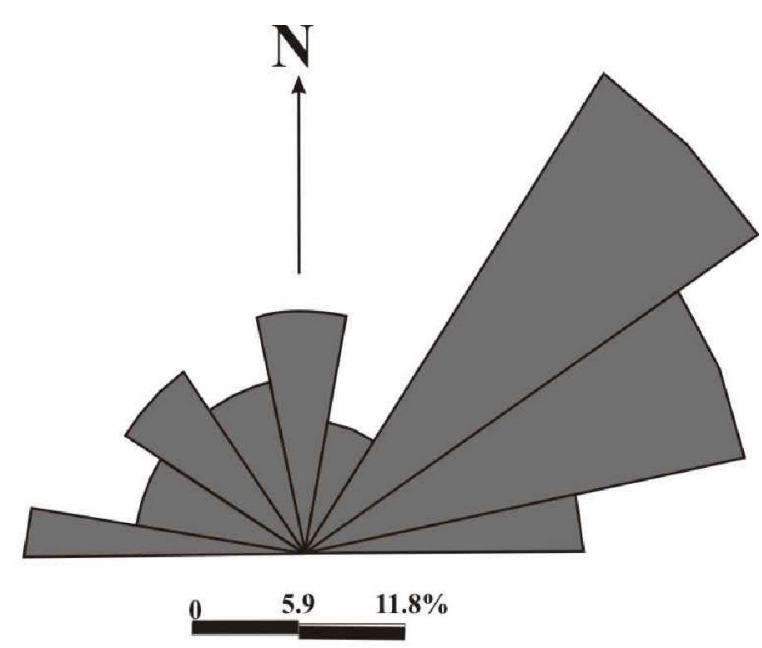

(b)

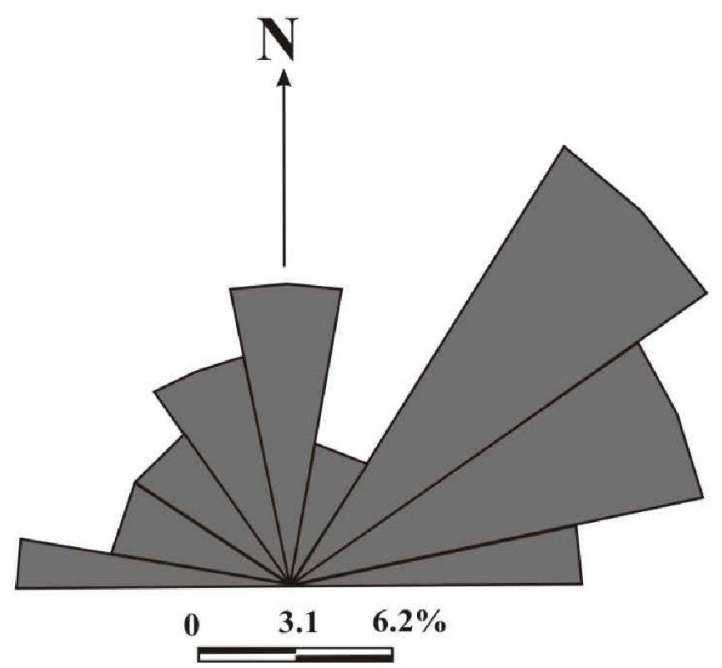

Fig. 13: Rose diagrams showing the main directional trends of 101 fault lines according to their number (a) and length (b) proportion.

\section{Radioactivty and Uranium Potentialities}

\subsection{Radioactivity of the Different Rock Types}

Radiometric survey was conducted to this area due to the presence of abundant granitic rocks of different types, contacts with other older volcanic rocks. Remarkable features of late magmatic pneumatolytic phase and post-magmatic hydrothermal products such as pegmatite and aplite formation and different wall rock alterations associated with these granites. These were the main reasons of choosing the area for radiometric survey and uranium exploration. From the first glance, one can expect the importance of granitic rocks over the other types of rocks due to the increase of their backgrounds in uranium content as demonstrated in table (1).

The field radiometric survey had been done using RS-230 multi-channel gamma ray spectrometer which was calibrated in the Laboratory of Nuclear Materials Authority of Egypt (NMA). A number of representative samples from these two types of granites was collected and radiometrically measured in the labs table (2). 
Table 1: Showing the radioactivity measurements (in the field $\&$ laboratories) of the different rock types in the study area.

\begin{tabular}{|c|c|c|c|c|c|}
\hline \multirow{3}{*}{ Rock Type } & \multicolumn{5}{|c|}{ Field measurements (ppm) } \\
\hline & \multirow[t]{2}{*}{ No. of measurements } & \multicolumn{2}{|c|}{ eU (ppm) } & \multirow{2}{*}{$\begin{array}{c}\text { eTh(ppm) } \\
\text { Range }\end{array}$} & \multirow[b]{2}{*}{ Average } \\
\hline & & Range & Average & & \\
\hline Metavolcanics & 98 & $11-3.4$ & 24 & $28-92$ & 69 \\
\hline Dokhan volcanics & 220 & $1.9-10.1$ & 3.8 & $4.6-324$ & 10.7 \\
\hline Syenogranties & 170 & $3.0-9.1$ & 6.8 & $9.7-33.9$ & 19.4 \\
\hline Alkali feldspar granites & 195 & $3.0-21.0$ & 9.2 & $8.9-37.8$ & 24.3 \\
\hline Pegmatites & 40 & $9.2-41.7$ & 27.4 & $22.6-71.9$ & 42.5 \\
\hline Acidic dykes & 60 & $3.8-9.2$ & 6.5 & $126-29.3$ & 22.7 \\
\hline Intermediate dykes & 21 & $2.0-3.1$ & 2.8 & $4.8-8.7$ & 6.1 \\
\hline Basic dykes & 30 & $<1.0-2.4$ & 1.8 & $2.9-7.1$ & 5.3 \\
\hline
\end{tabular}

Table 1: Cont.

\begin{tabular}{|c|c|c|c|c|c|c|c|c|}
\hline \multirow{3}{*}{ Rock Type } & \multicolumn{8}{|c|}{ Laboratory measurements (ppm) } \\
\hline & \multicolumn{2}{|l|}{ eU (ppm) } & \multicolumn{2}{|c|}{ eTh(ppm) } & \multicolumn{2}{|l|}{ eRa(ppm) } & \multicolumn{2}{|l|}{ K\% } \\
\hline & Range & Average & Range & Average & Range & Average & Range & Average \\
\hline Metavolcanics & $1.32-3.73$ & 2.86 & $4.42-11.26$ & 7.89 & $2.0-3.0$ & 2.3 & $0.75-1.43$ & 1.23 \\
\hline Dokhan volcanics & $1.0-10.41$ & 4.11 & $5.84-32.10$ & 11.28 & $3.0-44.0$ & 3.6 & $0.84-2.65$ & 1.60 \\
\hline Syenogranties & $3.77-8.87$ & 4.80 & $13.32-33.18$ & 18.60 & $3.0-9.0$ & 4.1 & $2.31-3.22$ & 2.88 \\
\hline Alkali feldspar granites & $3.46-20.61$ & 7.56 & $12.86-42.81$ & 25.67 & $4.0-12.0$ & 6.5 & $2.58-3.43$ & 2.98 \\
\hline Pegmatites & $11.81-49.77$ & 28.72 & $23.15-78.25$ & 44.47 & $3.0-8.0$ & 4.5 & $2.48-3.16$ & 2,84 \\
\hline Acidic dykes & $4.35-10.56$ & 6.75 & $14.21-31.10$ & 24.46 & $3.0-12.0$ & 6.0 & $2.40-2.95$ & 2.48 \\
\hline Intermediate dykes & $2.51-3.62$ & 3.12 & $5.14-9.18$ & 7.53 & $30-70$ & 4.8 & $1.67-2.33$ & 1.89 \\
\hline Basic dykes & $<1.0-2.84$ & 2.1 & $3.01-7.88$ & 6.01 & $2.0-3.0$ & 2.2 & $1.12-1.81$ & 1.39 \\
\hline
\end{tabular}

\subsection{Radioactive Anomalies}

Through the conducted radiometric survey, a great emphasis was paid to the younger granitic rocks and related pegmatites. These rocks when examined in the field it was found that they bear a key feature that indicate an increase in the probability for finding radioactive anomalies or simply an increase for uranium and/or thorium concentrations several times over their background. Hence, the uranium is known to be enriched in the late stages of magmatic crystallization and post magmatic processes. Search for hydrothermal wall rock alterations as well as pegmatites and aplite became favorable targets.

The discovered two radioactive anomalies in the area are hosted in the more differentiated granite which is the alkali feldspar granite type especially in its associated pegmatites. These pegmatites are located along W. Al Shayilah and are considered the products of the late magmaticpneumatolytic process that associated with the prevailing of volatiles in the residual melt as well as uranium and associated elements. A detailed field description of these radiometric anomalies is given in the following paragraphs:

\subsubsection{Radioactive Anomaly No. 1}

This anomaly is located at the southern part of G. Urf Al Eeir alkali feldspar granites. The high gamma-radioactivity is linked to a pegmatite vein of $1.3 \mathrm{~m}$ width and can be traced clearly for $15-20$ meters length extending in the ENE-WSW direction (Fig. 14). The granites surrounding the pegmatite vein are highly altered and are cut by acidic and basic dykes as well as veins of quartz with abundant hematitic staining on the walls of joints (Fig. 15). The vein is somewhat showing a zoning characters 
where the K-feldspars are concentrated near the outer rims of the vein and the central parts are mainly filled with quartz and micas.

Table 2: Uranium and Thorium concentration chemically and radiometrically in the two types of the granites.

\begin{tabular}{|c|c|c|c|c|c|c|c|}
\hline \multirow[t]{2}{*}{ Rock type } & \multirow{2}{*}{$\begin{array}{c}\text { Sample } \\
\text { No. }\end{array}$} & \multicolumn{3}{|c|}{ Chemical analyses } & \multicolumn{3}{|c|}{ Radiometric analyses } \\
\hline & & U (ppm) & Th (ppm) & $\mathbf{T h} / \mathbf{U}$ & eU (ppm) & eTh (ppm) & eTh/eU \\
\hline \multirow{13}{*}{ Syenogranite } & GHS-1 & 4.30 & 16.80 & 3.91 & 3.91 & 17.92 & 4.58 \\
\hline & GHS-5 & 9.21 & 31.23 & 3.39 & 8.87 & 33.18 & 3.74 \\
\hline & GHS-8 & 4.94 & 18.40 & 3.72 & 4.62 & 22.51 & 4.87 \\
\hline & GHS-11 & 4.11 & 13.20 & 3.21 & 3.85 & 15.52 & 4.03 \\
\hline & GHS-23 & 5.70 & 15.80 & 2.77 & 5.09 & 15.06 & 2.96 \\
\hline & GHS-43 & 6.60 & 19.16 & 2.90 & 5.44 & 21.53 & 3.96 \\
\hline & GO-4 & 4.09 & 12.40 & 3.03 & 3.77 & 14.72 & 3.90 \\
\hline & GO-5 & 4.23 & 14.40 & 3.40 & 3.86 & 15.98 & 4.14 \\
\hline & GO-6 & 4.18 & 16.10 & 3.85 & 3.91 & 19.06 & 4.87 \\
\hline & GO-7 & 5.60 & 15.90 & 2.84 & 5.14 & 19.15 & 3.73 \\
\hline & GO-8 & 4.07 & 13.00 & 3.17 & 3.81 & 15.22 & 3.99 \\
\hline & GO-11 & 5.50 & 11.43 & 2.08 & 5.27 & 13.32 & 2.53 \\
\hline & Average & 5.21 & 16.49 & 3.16 & 4.80 & 18.60 & 3.88 \\
\hline \multirow{21}{*}{$\begin{array}{l}\text { Alkali } \\
\text { feldspar } \\
\text { granite }\end{array}$} & GH-1 & 9.45 & 32.00 & 3.39 & 8.39 & 33.81 & 4.03 \\
\hline & GH-2 & 9.80 & 25.40 & 2.59 & 9.12 & 26.78 & 2.94 \\
\hline & GH-3 & 10.65 & 33.70 & 3.16 & 9.92 & 32.71 & 3.30 \\
\hline & GH-4 & 9.55 & 31.60 & 3.31 & 8.47 & 33.59 & 3.97 \\
\hline & GH-5 & 8.70 & 28.60 & 3.29 & 7.26 & 31.11 & 4.29 \\
\hline & GH-6 & 21.30 & 39.10 & 1.84 & 20.61 & 38.10 & 1.85 \\
\hline & GH-7 & 8.55 & 30.90 & 3.61 & 7.19 & 32.18 & 4.48 \\
\hline & GH-8 & 9.45 & 33.30 & 3.52 & 8.45 & 34.65 & 4.10 \\
\hline & GH-9 & 7.58 & 32.40 & 4.27 & 6.59 & 33.98 & 5.16 \\
\hline & GH-10 & 14.30 & 37.50 & 2.62 & 13.88 & 42.81 & 3.08 \\
\hline & GSH-1 & 5.92 & 18.30 & 3.09 & 5.64 & 21.85 & 3.87 \\
\hline & GSH-2 & 5.22 & 13.80 & 2.64 & 5.02 & 15.36 & 3.06 \\
\hline & GSH-3 & 6.20 & 16.00 & 2.58 & 5.89 & 17.58 & 2.98 \\
\hline & GSH-4 & 5.80 & 14.00 & 2.41 & 5.16 & 15.95 & 3.09 \\
\hline & GSH-5 & 4.10 & 14.80 & 3.61 & 3.93 & 16.37 & 4.17 \\
\hline & GSH-6 & 4.80 & 10.20 & 2.13 & 4.53 & 12.86 & 2.84 \\
\hline & GSH-7 & 3.61 & 13.20 & 3.66 & 3.46 & 16.45 & 4.75 \\
\hline & GSH-8 & 5.70 & 13.50 & 2.37 & 5.11 & 16.57 & 3.24 \\
\hline & GSH-9 & 7.30 & 20.30 & 2.78 & 6.49 & 21.95 & 3.38 \\
\hline & GSH-10 & 7.90 & 16.10 & 2.04 & 6.15 & 18.68 & 3.04 \\
\hline & Average & 8.29 & 23.74 & 2.86 & 7.56 & 25.67 & 3.39 \\
\hline
\end{tabular}




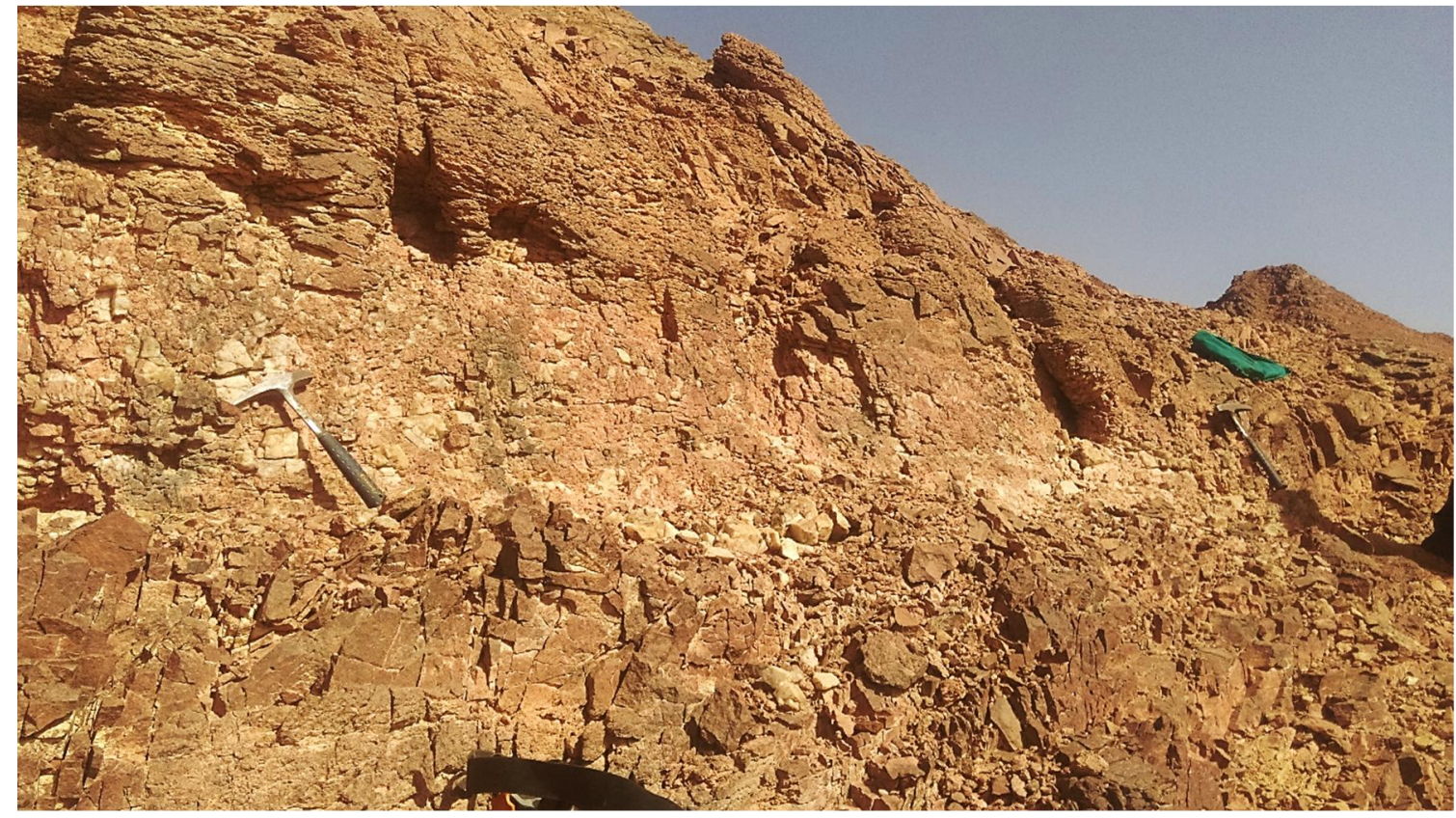

Fig. 14: The radioactive pegmatite vein associated with alkali feldspar granites in G. Urf El Eeir, looking NNE, Anomaly No. 1

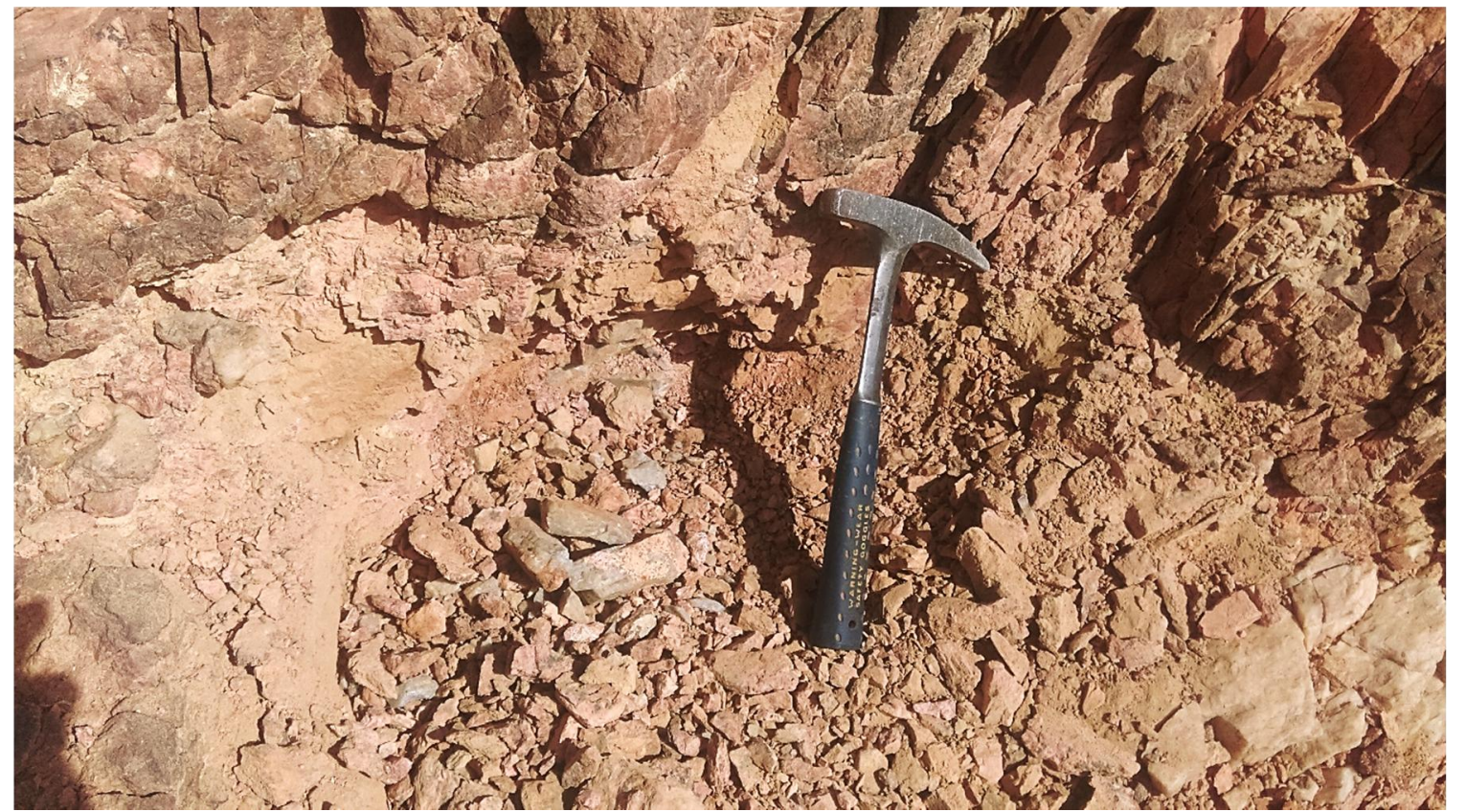

Fig. 15: Hematitization associated with the radioactive pegmatite vein, looking NE, Anomaly No. 1

The radiometric field measurements of the anomalous zone (Fig. $16 \mathrm{a}$ and b), indicate the presence of elongated and stretched high radioactive zone strongly controlled by the pegmatite vein. The background gamma radioactivity of the alkali feldspar granites near the radioactive anomaly is $350 \mathrm{cps}$, while the pegmatite vein has a gamma radioactivity up to $3600 \mathrm{cps}$. The laboratory measurements for the grab sample collected from this anomalous zone indicate that the equivalent uranium (eU) content equal $303 \mathrm{ppm}$, while the equivalent thorium (eTh) is $43 \mathrm{ppm}$ revealing the enrichment of uranium in this location (uranium anomaly). 

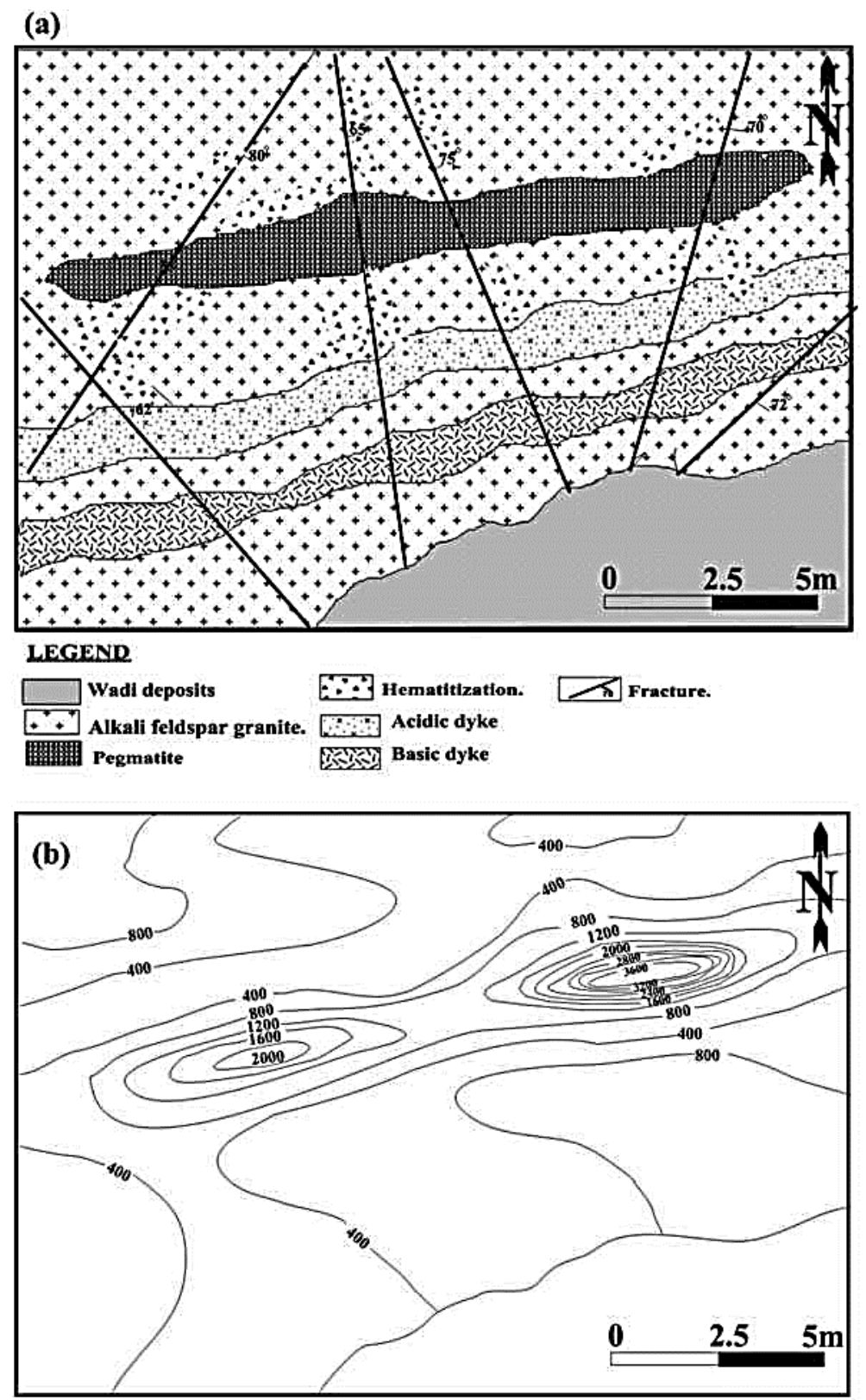

Fig. 16: Detailed geological map (a) and Radiometric map (in Ur) (b) of the radioactive Anomaly No. 1.

\subsubsection{Radioactive anomaly No. 2}

This anomaly is discovered in the alkali feldspar granite of G. Al Shayilah. The anomalous zone (Fig. $17 \mathrm{a} \& \mathrm{~b}$ ) is relatively restricted to a zoned pegmatite body of $4 \mathrm{~m}$ long x $2 \mathrm{~m}$ width in the granite. The pegmatite body is roughly aligned and controlled by the intersection of the joints striking $\mathrm{N} 60^{\circ} \mathrm{E}$ and $\mathrm{N} 65^{\circ} \mathrm{W}$. This pegmatite contains clear crystals of quartz mega-crystals in its core part and a rim of $\mathrm{K}$-feldspar and pockets of mica and iron (Fig. 17b). The granite around the anomalous pegmatites is highly silicified and invaded by numerous silica veins (Fig. 18a). The highest radioactivity values are associated with the core of this pegmatite which is enriched with iron and mica (Fig. 18a). This may be attributed to the effect of presence of mica as a reductant and can fix and absorb uranium between its sheet structures (flackes).

The field measurements of the gamma activity around the anomalous pegmatites show wide range of variation between the backgrounds of fresh alkali feldspar granites which equal $540 \mathrm{cps}$ and the gamma activity of the anomalous pegmatites which reach up to $4500 \mathrm{cps}$ (Fig.18b). The analyzed grab sample collected from this anomalous zone gave eU content of $246 \mathrm{ppm}$, while the eTh is $73 \mathrm{ppm}$. 


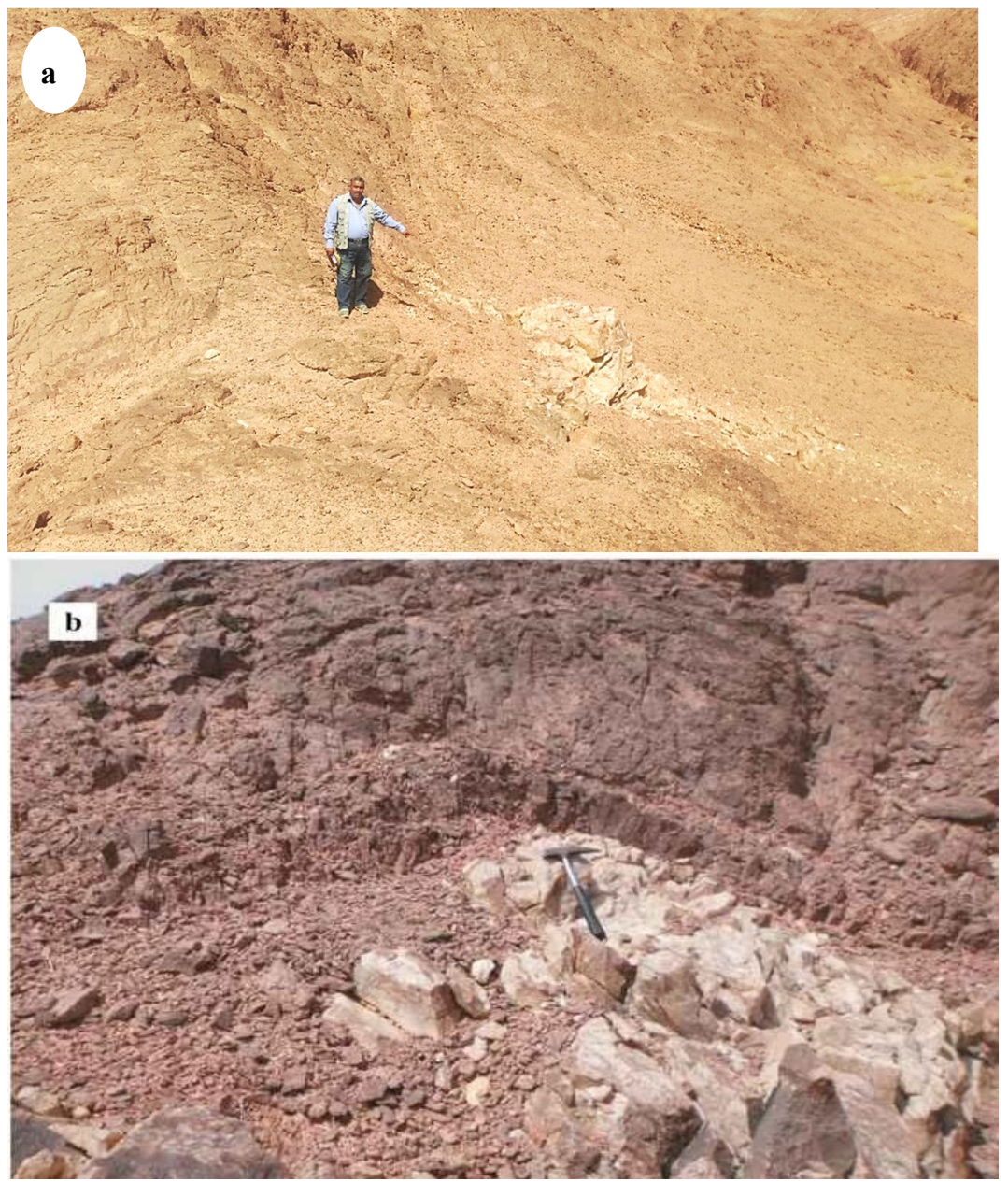

Fig. 17a \&b: The radioactive zoned pegmatites with its core has mega-quartz crystals and rimmed by k-feldsapr, looking NW, Anomaly No. 2.

From the previously mentioned statement and relationships it is concluded that, the highly enriched granite in uranium and/or thorium in the studied area is the alkali feldspar granite. Background uranium contents of the alkali feldspar granite are high (av. $8.29 \mathrm{ppm}$ ), whereas, the normal uranium content for granite is considered to be 4ppm (Rogers and Adams, 1969; Cuney, 1978). The high background of $U$ classified this type of granite as anomalous and/or uraniferous granite. The uranium source to generate the secondary uranium minerals is the hydrothermal fluids associated with the late stages of magmatic process.

Refering to the recorded radioactive anomalies in the area, it is noticed that the hydrothermal activities associated with the later phase of the granitic magmas had played critical roles in the formation of these anomalies. The studied area is cut by different structure elements like faults, fractures and joints trending approximately to NE-SW, ENE-WSW, and N-S directions. Generally, these trends are affected by hydrothermal alterations along their planes and locally associated with secondary uranium minerals in the younger granite. In the present case, the documented radioactive anomalies are principally observed at the intersection of fractures. The most radioactive anomalous cross fractures are the NW-SE with ENE-WSW and WNW-ESE trends.

The NNW-SSE (Dextral faults) and the NE-SW (Sinistral faults) constitute two conjugate faults system where $\left(\boldsymbol{\sigma}_{1}\right)$ compressive stress causing them are directed $\mathrm{N} 15^{\circ} \mathrm{E}$ (Fig. 19). This compression force creates an extensional regime in the normal direction NW-SE which causes the pulling of the area from the NW and SE directions. This tensile stress causes a rejuvenation of the early formed fault trends such as the WNW-ESE and the ENE-WSW (Fig. 20). 


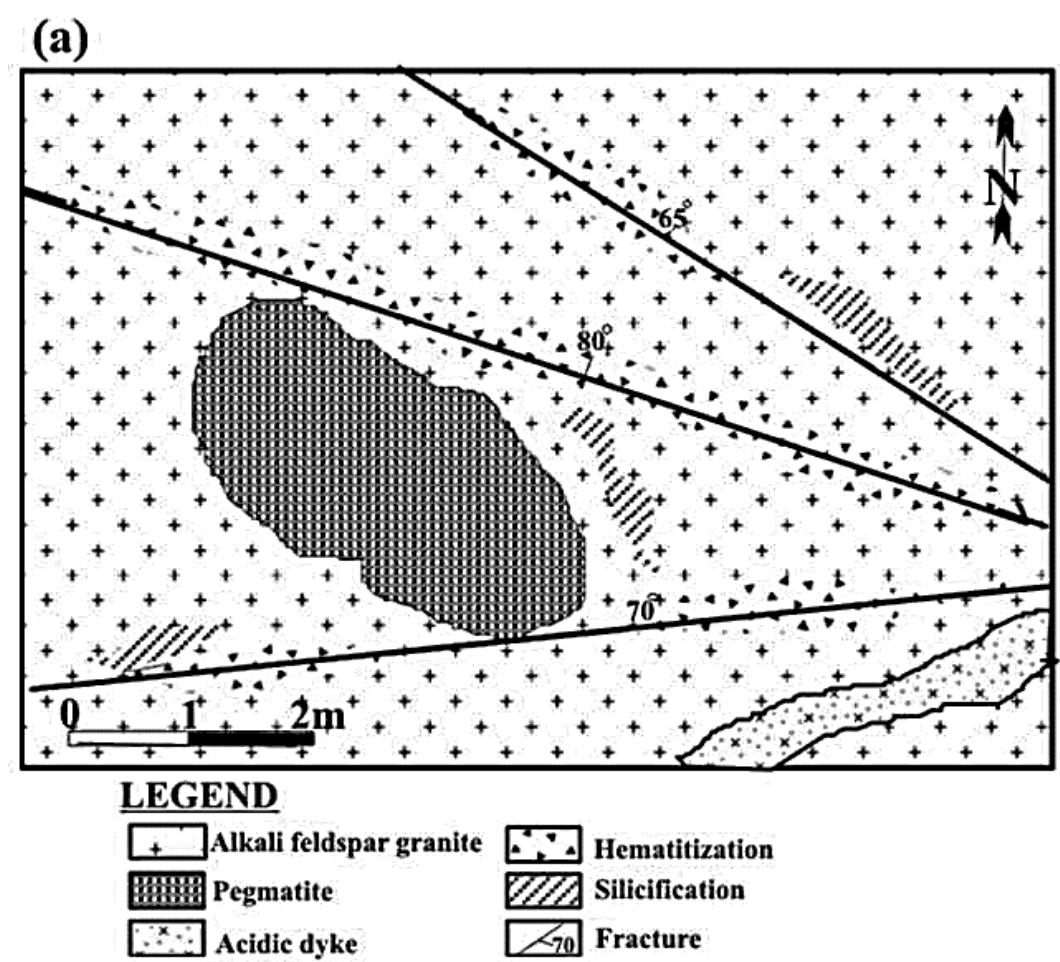

(b)

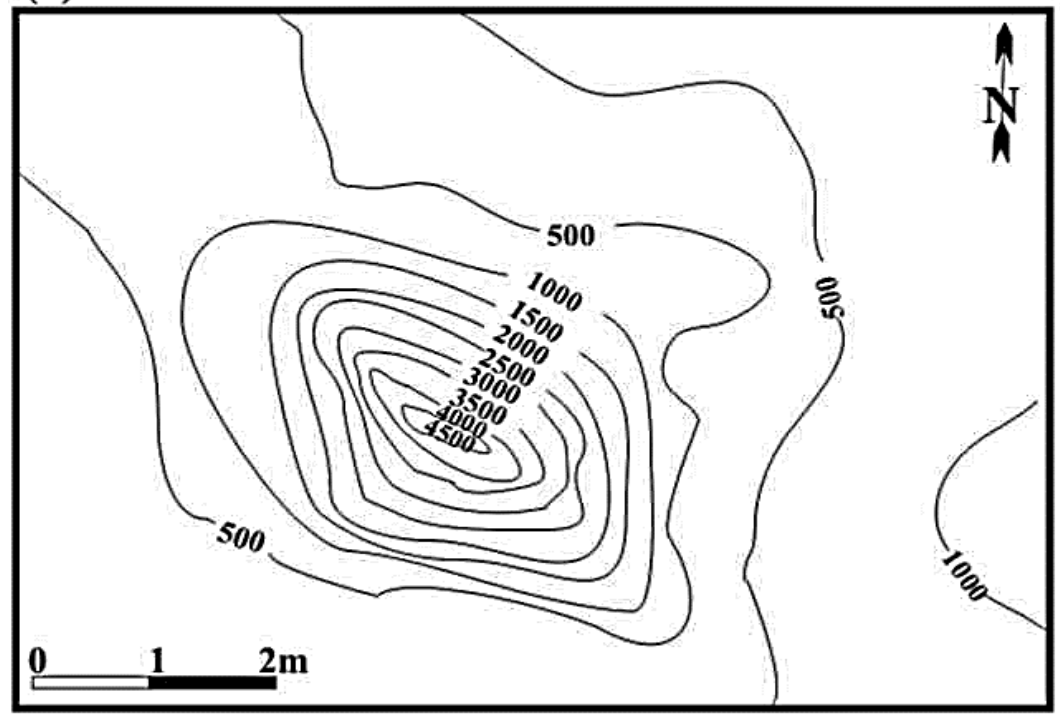

Fig. 18: Detailed geological map (a) and radiometrical map (in Ur) (b) of the radioactive anomaly site No. 2

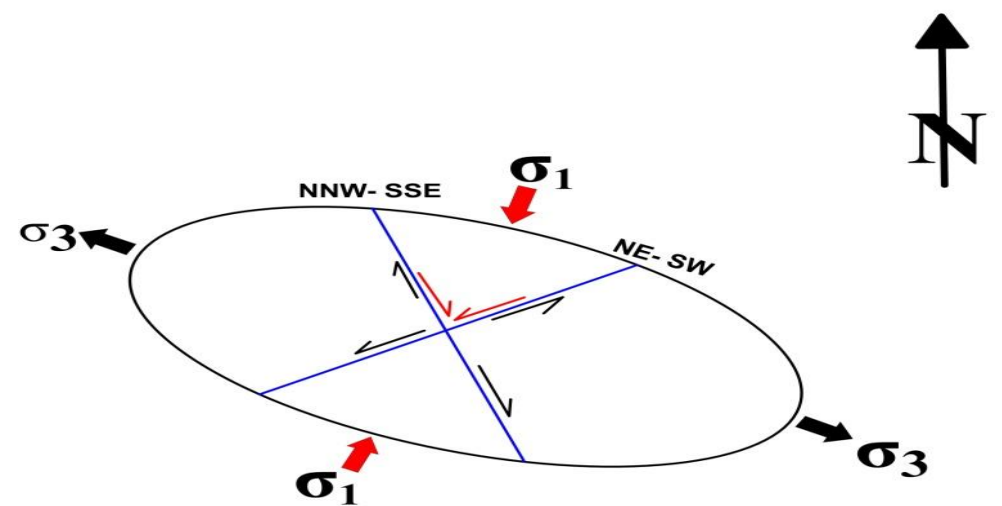

Fig. 19: Stage 1 showing the $\mathrm{N} 15^{\circ} \mathrm{E}$ compression and the two conjugate fault trends 


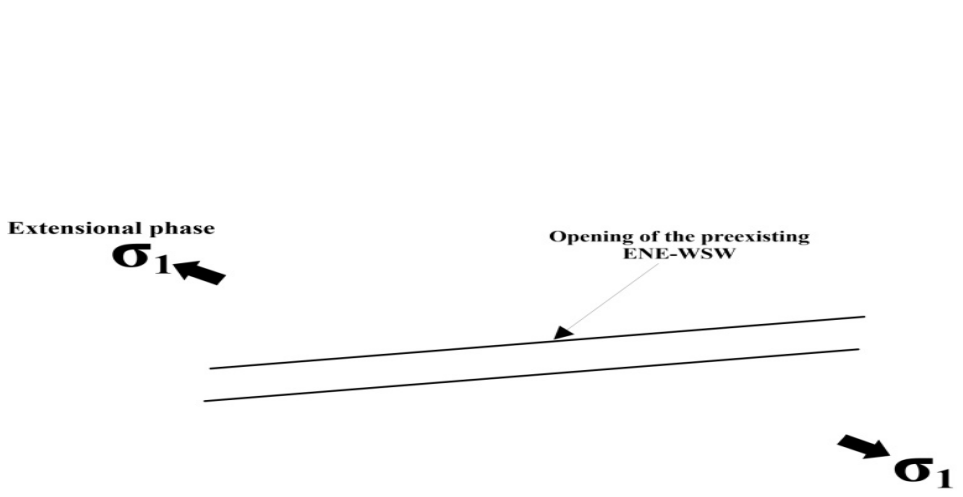

Fig. 20: Stage 2 Showing extensional force directed NW and SE causing the opening of the ENEWSW older trends.

This extensional force open these older ENE-WSW fractures causing the ascending of the late magmatic fluids rich in volatiles and carrying the uranium mineralization which causing the filling of these faults with the pegmatite materials in the late magmatic stages as well as the hydrothermal fluids enriched with uranium which is the case of the anomaly No. 1 of the pegmatite vein. The same mechanisms can also explain clearly the presence of a large pegmatite body of anomaly No. 2 which is controlled by, and enclosed within, the intersection of E-W and NW-SE faults in the direction of pressure release. This indicate the structural control of these anomalous zones containing the pegmatite bodies and the role played by the structure in localizing the uranium in the area.

\subsection{Mineralogy of Uranium Mineralization}

The mineralogical studies for the accessory minerals of the investigated granites played an important role in the formation of the uranium mineralizations. The types of granite have nearly the same accessory mineral composition, which decrease in proportions toward the alkali feldspar granite. Overall, the accessory mineral assemblages are mainly composed of zircon, sphene, fluorite, columbite, allanite and apatite and most of them are bearing uranium with different percentages.

The secondary uranium mineralizations are of the anomalous pegmatite of the alkali feldspar granite are mainly represented by uranophane and kasolite. Detailed microscopic investigations supported by X-ray diffraction (XRD) and Energy Dispersive X-ray (EDX) analyses are used for the identification of the radioactive minerals.

\subsubsection{Secondary uranium minerals}

Most of the mineralized radioactive samples contain uranophane $\left[\mathrm{Ca}\left(\mathrm{UO}_{2}\right)_{2} \mathrm{SiO}_{3}(\mathrm{OH})_{2} \cdot 5 \mathrm{H}_{2} \mathrm{O}\right]$ and kasolite $\left[\mathrm{Pb}\left(\mathrm{UO}_{2}\right)\left(\mathrm{SiO}_{4}\right) \cdot \mathrm{H}_{2} \mathrm{O}\right]$. The abuandance of each mineral differs in the two anonalies where Kasolite is more abundant in the pegmatite vein of anomaly No.1 while Uranophane is more abundant than kasolite in the pegmatite pocket of anomaly No.2.

\subsubsection{Uranophane $\left[\mathrm{Ca}\left(\mathrm{UO}_{2}\right)_{2} \mathrm{SiO}_{3}(\mathrm{OH})_{2} \cdot 5 \mathrm{H}_{2} \mathrm{O}\right]$}

Uranophane is one of the most common secondary uranium minerals. It represents the most abundant and widely distributed of various uranium silicate composite of a hydrate $\mathrm{Ca}, \mathrm{U}$ silicates. It is a monoclinic uranyl silicate mineral fairly common in the oxidized zone of most uranium deposits (Cebron, et al., 1993). It is considered as alteration product of uraninite but recent research works indicate that they can be also precipitated and formed directly from hyrothermal fluids and/or meteoric water (Stohl et al., 1981). Under binocular microscope, The uranophane grains, separated from the studied samples, are generally massive with granular form, have their luster is dull and greasy. These grains are distinguished by their bright colors (canary to lemon yellow) with pale yellow streak.

Raslan (2004) remarked that the presence of both uranophane and beta-uranophane as a mixture in some samples is attributed to the presence of both habits (massive granular and fibrous acicular 
crystals) as intergrown mixtures. It is closely associated with late-stage $\mathrm{Fe}$ and $\mathrm{Mn}$ oxide alteration. These alterations could be considered as a good trap for uranium- and thorium bearing minerals.

$\mathrm{X}$-ray diffraction patterns for some selected grains from uranophane is presented in Table (3). The Environmental Scanning Electron Microscope (ESEM) microphotograph and EDX (Energy Dispersive X-ray) analyses of some uranophane mineral grains reveal that the mineral is essentially composed of $\mathrm{U}, \mathrm{Ca}$ and $\mathrm{Si}$, with traces of $\mathrm{Al}, \mathrm{K}$ and Fe (Fig. 21 a and b).

\subsubsection{Kasolite $\left[\mathrm{Pb}\left(\mathrm{UO}_{2}\right)\left(\mathrm{SiO}_{4}\right) \cdot \mathrm{H}_{2} \mathrm{O}\right]$}

Kasolite is characterized by its bright canary lemon colors, yellow and brown of different intensities. Kasolite grains are relatively harder compared with other uranium secondary minerals (Raslan 1996). This U- mineral is close in its physical properties and morphological features to uranophane and characterized by its softness to crushing. Kasolite is generally distinguished from the other uranium silicates by its crystal habit and luster (Dawood et al., 2010). This mineral is a hydrated silicate of lead and hexavalent uranium and is the only uranyl silicate with lead as major cation. The studied grains usually occur as massive granular form and of yellowish brown color (Fig.22a). It are characterized by their waxy or greasy luster.

X-ray diffraction patterns for some selected grains of kasolite presented in Table (3). The ESEM microphotograph and EDX data of kasolite mineral grains reflect the major elements in the kasolite mineral; U, Pb, Si and K (Fig. 22b).

Table 3: X-ray diffraction patterns of secondary uranium minerals picked from the mineralized pegmatite of the alkali feldspar granite.

\begin{tabular}{|c|c|c|c|c|c|}
\hline \multicolumn{2}{|c|}{ Analyzed sample } & \multicolumn{2}{|c|}{ Uranophane (8-0301)* } & \multicolumn{2}{|c|}{ Kasolite( 8-0297)* } \\
\hline $\mathbf{d A}^{\mathbf{0}}$ & $\mathbf{I} / \mathbf{I}^{\circ}$ & $\mathbf{d A}^{0}$ & $\mathbf{I} / \mathbf{I}^{\circ}$ & $\mathbf{d A}^{\mathbf{0}}$ & $\mathbf{I} / \mathbf{I}^{\circ}$ \\
\hline 7.89 & 100 & 7.88 & 100 & & \\
\hline 6.57 & 10 & 6.61 & 40 & 6.61 & 60 \\
\hline 6.13 & 9 & 5.42 & 40 & 6.19 & 20 \\
\hline 4.81 & 13 & 4.76 & 50 & 5.31 & 40 \\
\hline 4.24 & 24 & 4.29 & 20 & 4.19 & 80 \\
\hline 4.11 & 27 & 3.94 & 90 & & \\
\hline 3.96 & 14 & 3.60 & 40 & & \\
\hline 3.54 & 31 & 3.51 & 40 & 3.53 & 70 \\
\hline 3.36 & 16 & 3.20 & 50 & 3.38 & 10 \\
\hline 3.25 & 100 & & & 2.26 & 100 \\
\hline 3.20 & 23 & 3.09 & 10 & & \\
\hline 3.09 & 18 & 2.99 & 80 & 3.07 & 50 \\
\hline 2.99 & 14 & 2.91 & 80 & & \\
\hline 2.91 & 38 & 2.69 & 40 & 2.93 & 90 \\
\hline 2.70 & 6 & 2.63 & 50 & 2.73 & 30 \\
\hline 2.57 & 10 & 2.57 & 20 & 2.64 & 30 \\
\hline 2.49 & 4 & 2.52 & 20 & 2.47 & 30 \\
\hline 2.40 & 8 & 2.40 & 10 & 2.42 & 20 \\
\hline 2.34 & 3 & 2.26 & 20 & 2.37 & 20 \\
\hline 2.17 & 9 & 2.20 & 40 & 2.18 & 30 \\
\hline 2.12 & 7 & & & 2.11 & 20 \\
\hline 2.08 & 5 & 2.10 & 50 & 2.05 & 30 \\
\hline I .99 & 10 & 2.06 & 20 & 1.962 & 50 \\
\hline 1.96 & 12 & 1.969 & 70 & & \\
\hline 1.89 & 10 & 1.906 & 20 & 1.876 & 20 \\
\hline 1.83 & 4 & 1.867 & 30 & 1.826 & 10 \\
\hline 1.77 & 15 & 1.769 & 30 & 1.741 & 40 \\
\hline 1.74 & 3 & 1.717 & 10 & & \\
\hline 1.69 & 10 & 1.659 & 20 & 1.677 & 50 \\
\hline 1.61 & 2 & 1.601 & 10 & 1.623 & 10 \\
\hline
\end{tabular}

(*) ASTM Card Number 


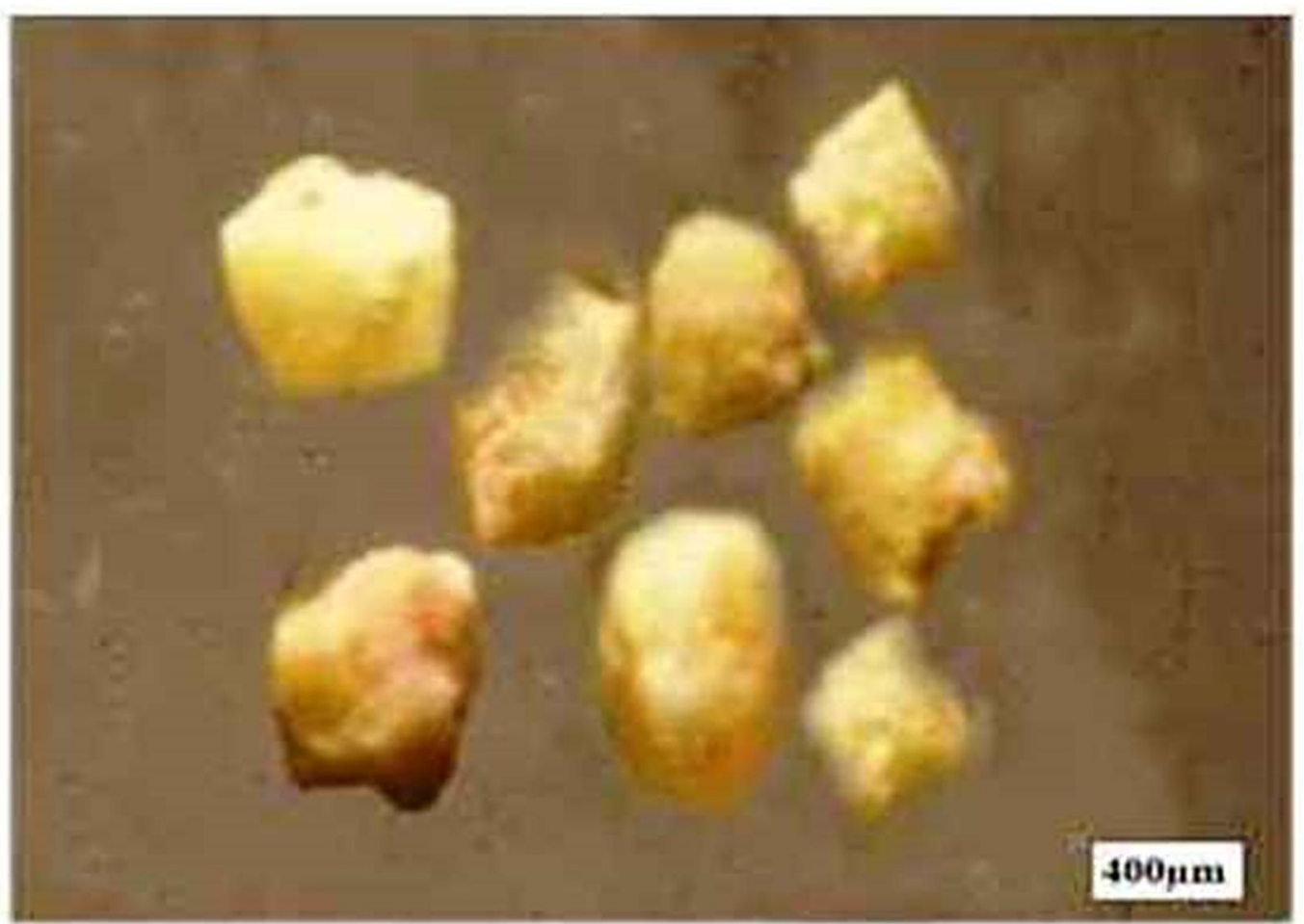

Fig. 21-a: Photomicrograph of uranophane grains picked from the mineralized alkali feldspar granite.

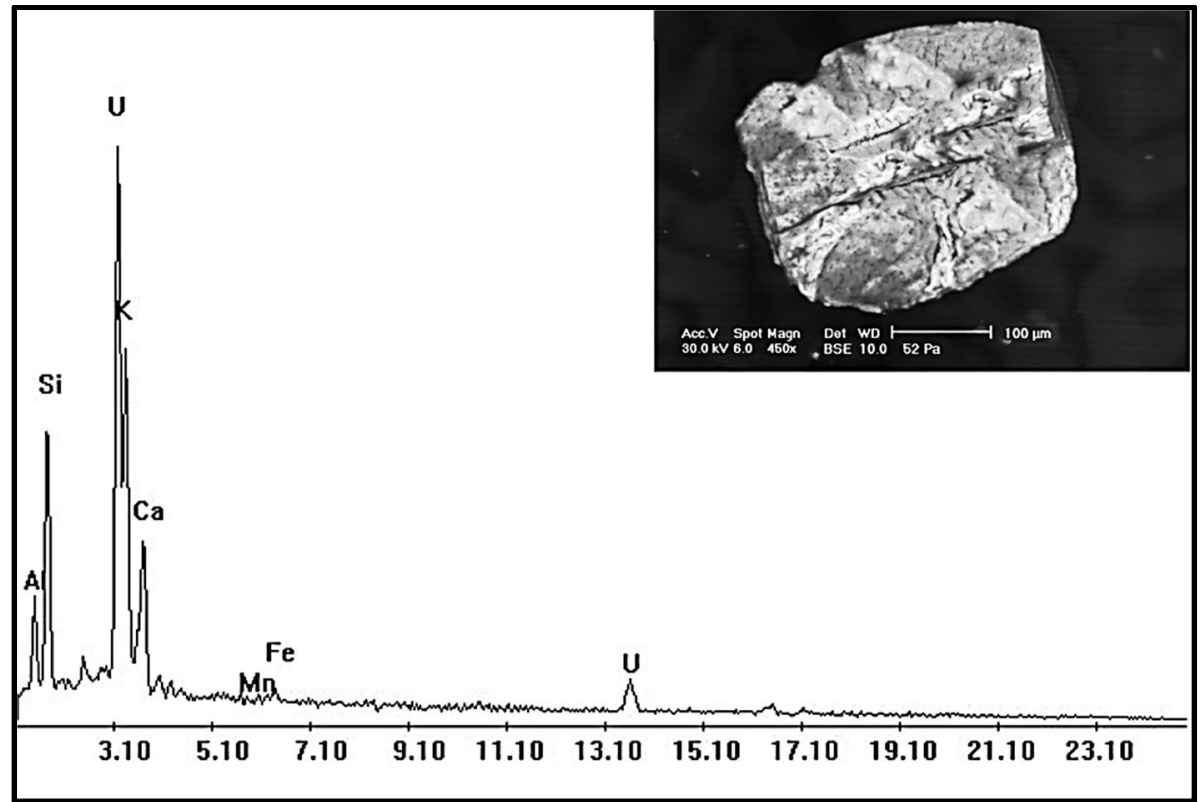

Fig. 21-b: ESEM image and its EDX spectrum of uranophane mineral. 


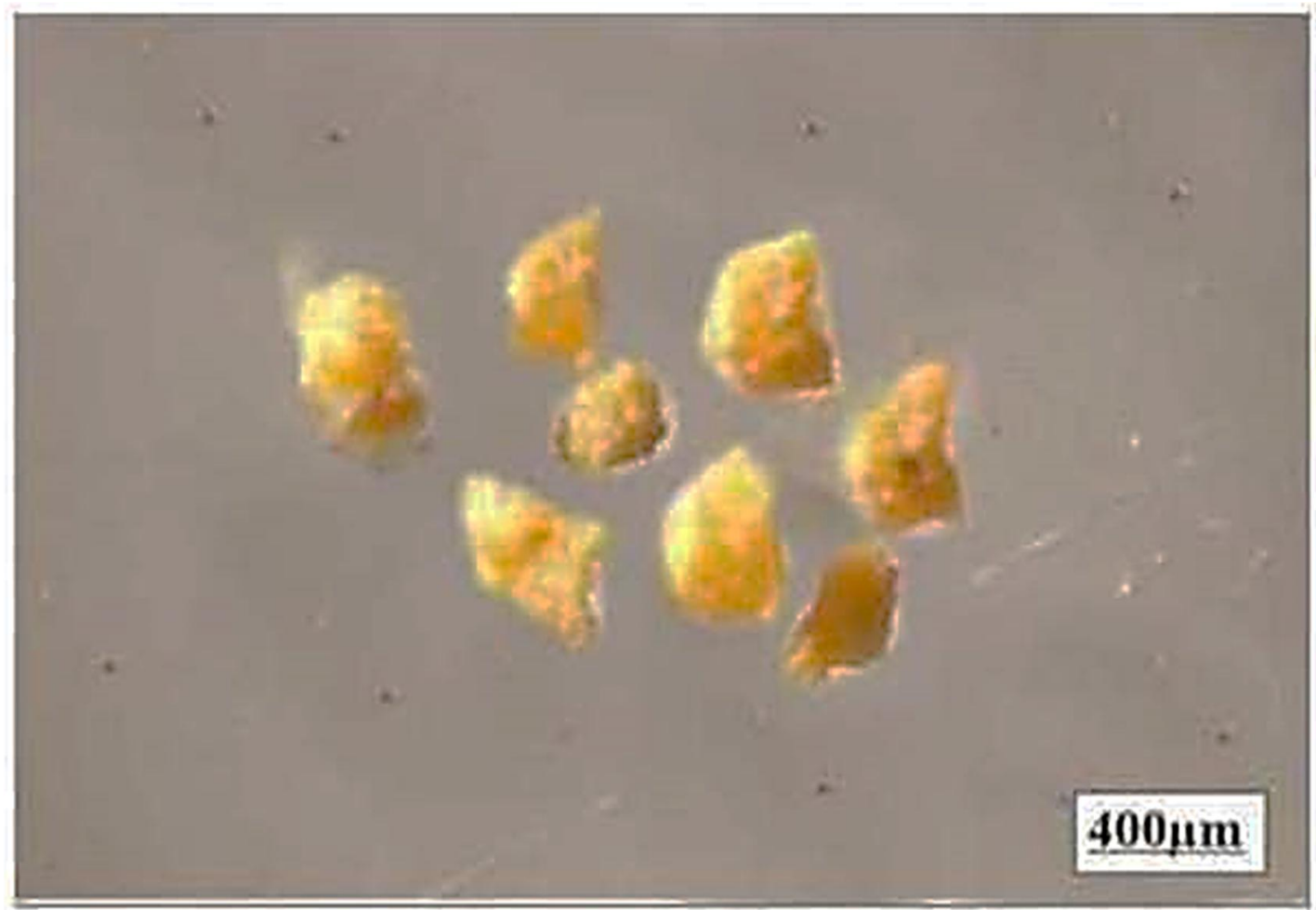

Fig. 22-a: Photomicrograph of kasolite grains picked from the mineralized pegmatite of the alkali feldspar granite

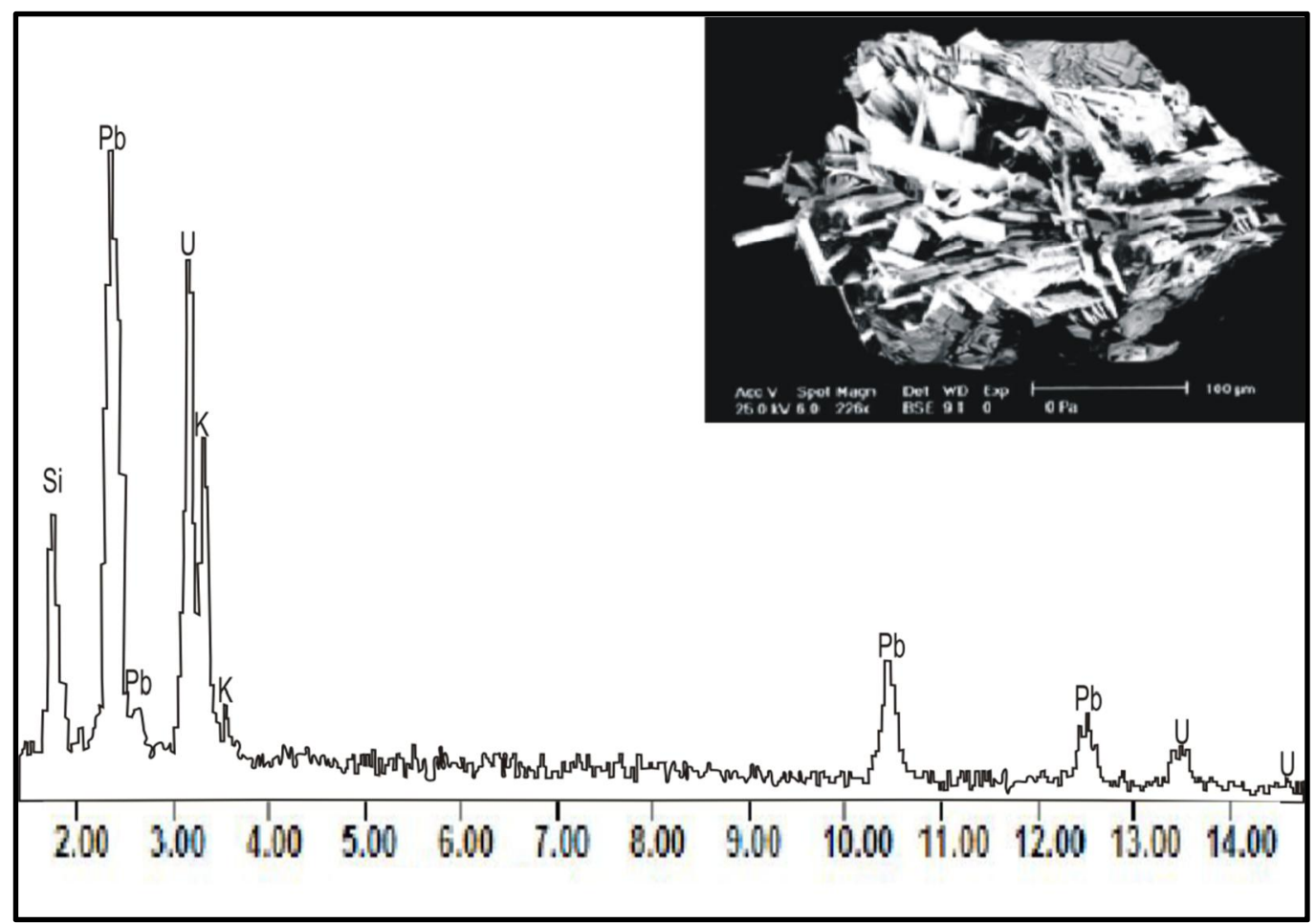

Fig. 22-b: ESEM image and its EDX spectrum of Kasolite mineral.

\section{Conclusions}

Wadi Al Shayilah area was chosen as a target for uranium exploration due to the presence of more than one type of younger granitic intrusions covering most of the area which are the syenogranites of G. El Hurous and W. Abu Harba and the alkali feldspar granites G. Al Shayilah, W. Al Shayilah and G. Urf El Eeir. These granites, in addition to older rocks of island arc metavolcanics 
and within plate late orogenic Dokhan volcanics, are covering most of the study area. The island arc metavolcanics are represented by metabasalt, metadolerite, metabasaltic andesite and meta-andesite with very rare or no metapyroclastics. Dokhan volcanics are mainly represented by andesite, andesite porphyry, dacite, rhyodacite and rhyolites as lava flows where the more basic varieties such as basaltic andesite are very rare and never repeated in the volcanics sequence. These volcanics also includes a big amount of pyroclastics such as agglomerates, lapilli, lapilli-tuffs and tuffs of intermediate to acidic composition.

Syenogranite is generally equigranular and composed of potash feldspar, quartz, plagioclase and biotite as essential minerals. The accessory minerals include zircon, sphene, muscovite, apatite and iron oxides, while epidote and chlorite are secondary mineral. The syenogranites can be classified as sub-solvus granite. Alkali feldspar granites are generally equigranular, medium to coarse-grained and mainly consists of potash feldspar, quartz, subordinate plagioclase, and few biotite as essential minerals. The main accessory minerals are opaque minerals, sphene, zircon and apatite, whereas the secondary minerals are chlorite, epidote, sericite, and muscovite. The mafic minerals are scarce giving rise to the leucogranite type.

The geologic and readiometric survey led to the discovery of two radioactive anomalies in the pegmatite veins and pockets associated with the alkali feldspar granites. These anomalies indicate an enrichment of uranium over thorium in these pegmatites. The first anomalous zone is pegmatite vein trending ENE-WSW has equivalent uranium (eU) content $303 \mathrm{ppm}$, while the equivalent thorium (eTh) is $43 \mathrm{ppm}$. The second anomalous pegmatite pocket is controlled by the intersection of the ENE-WSW and the NW-SE fractures gave eU content $246 \mathrm{ppm}$, while the eTh is $73 \mathrm{ppm}$ while their hosting alkali feldspar granite has an average uranium content $8 \mathrm{ppm}$ and thorium $23 \mathrm{ppm}$. The examined main radioactive secondary minerals causing these anomalies are uranophane and kasolite recorded in both radioactive pegmatites with different ratios.

An aero-radiometric survey is recommended for this important area due to its rough and high serrated topography which can record many other anomalies on both syenogranites and alkali feldspar granites. Car-borne radiometric survey could be conducted to cover vast area in this important sector of North Eastern Desert to increase the uranium potentiality of the area.

\section{Acknowledgment}

I am very grateful to my institution the Nuclear Materials Authority for supporting and facilitating in doing this work, to my colleagues in the Gattar project, and my colleagues in (NMA) labs at Kattamyia for their helping during this work.

\section{References}

Abdel Hamid, A.A., 2013. Mineralogical and geochemical studies of the uranium-bearing granites, Gabal Abu Harba area, North Eastern Desert, Egypt. Ph.D. Thesis, Fac. Sci. Benha Univ. 173.

Ali, K.A., A. Andresen, R.J. Stern, W.I. Manton, S.A. Omar, and A.E. Maurice, 2012. UPb zircon and $\mathrm{Sr}-\mathrm{Nd}-\mathrm{Hf}$ isotopic evidence for a juvenile origin of the c $634 \mathrm{Ma}$ El-Shalul Granite, Central Eastern Desert, Egypt. Geological Magazine, 149: 783-797.

Ali, K.A., B.A. Zoheir, R.J. Stern, A. Andresen, M.J. Whitehouse, and W.W. Bishara, 2016. Lu-Hf and $\mathrm{O}$ isotopic compositions on single zircons from the North Eastern Desert of Egypt, Arabian-Nubian Shield: Implications for crustal evolution. Gondwana Research, 32: 181-192.

Cesborn, F., P. Idefonse, and M.D. Sichere, 1993. New mineralogical data on uranophane and $\beta$ uranophane synthesis of uranophane. Ged. Magazine, 57: 301-308.

Cuney, M., 1978. Geologic environment, mineralogy, and fluid inclusions of the bois Noirs-Limouzat uranium vein, Forez, France. Econ. Geol., 73: 1567-1610.

Dawood, Y.H., H.M. Harbi, and H.H. Abd El-Naby, 2010. Genesis of kasolite associated with aplitepegmatite at Jabal Sayid, Hijaz region, Kingdom of Saudi Arabia. Journal of Asian Earth Sciences, 37: 1-9.

El Gaby, S., 1975. Petrochemistry and geochemistry of some granites from Egypt. Neues Jahrh. Min. Abh., 124: 147-189. 
El Kholy, D.M., 1999. Geology and radioactivity studies of the Dokhan Volcanics and Hammamat sediments, north Gabal Qattar, north Eastern Desert, Egypt. First Seminar on Nuclear Raw Materials and Their Technology, Cairo, Egypt, 1-31.

El Sayed, M.M., F.H. Mohamed, H. Furnes, and S. Kanisawa, 2002. Geochemistry and petrogenesis of the neoproterozoic granitoids in the Central Eastern Desert, Egypt. Chemie der Erde Geochemistry, 62(4): 317-346.

El Sayed, M.M., M.A. Obeid, H. Furnes, and A.M. Moghazi, 2004. Late Neoproterozoic volcanism in the southern Eastern Desert, Egypt: petrological, structural and geochemical constraints on the tectonic-magmatic evolution of the Allaqi Dokhan volcanic suite. N. Jb. Miner. Abh., 180 (3) : 261-286.

Eliwa, H.A., 2000. Petrology, geochemistry, mineral chemistry and petrogenesis of Samr El-Qaa Volcanics, North Eastern Desert, Egypt. Sci. J. Fac. Sci. Minufiya Univ. XIV, 1-45.

Eliwa, H.A., M.Z. El-Bialy, and M. Murata, 2014. Ediacaran post-collisional volcanism in the Arabian-Nubian Shield: The high-K calc-alkaline Dokhan Volcanics of Gabal Samr El-Qaa (592 $\pm 5 \mathrm{Ma}$ ), North Eastern Desert, Egypt. Precambrian Res., 246: 180-207.

El-Ramly, M.F., and M.K. Akaad, 1960. The basement complex in the central Eastern Desert of Egypt between latitudes $24^{\circ} 30^{\prime}$ and $25^{\circ} 40^{\prime}$ N. Geol. Surv. Egypt 8, 35p.

El-Shazly, E.M., 1964. On the classification of the Precambrian and other rocks of magmatic affiliation in Egypt. $22^{\text {nd }}$ Inter. Geol. Conger. Proc. Sect. 10, India 88 - 101.

Farahat, E.S., R. Zaki, C. Hauzenberger, and M. Sami, 2011. Neoproterozoic calc-alkaline peraluminous granitoids of the Deleihimmi pluton, Central Eastern Desert, Egypt: implications for transition from late- to post-collisional tectonomagmatic evolution in the northern ArabianNubian Shield. Geol. J., 46: 544-560.

Furnes, H., M.M. El Sayed, S.O. Khalil, and M.A. Hassanen, 1996. Pan-African magmatism in the Wadi El-Imra district, Central Eastern Desert, Egypt: geochemistry and tectonic environment. J. Geol. Soc. Lond. 153, 705-718.

Hume, W.F., 1935. Geology of Egypt. Geol. Surv. Egypt, Government press, Cairo, 2(2) : 301 - 688.

Hussein, A.A., M.M. Ali, and M.F. El Ramly, 1982. A proposed new classification of the granites of Egypt. J. Volc. Geoth. Res., 14: 187 - 198.

Khaled, S.H., 2021. Petrology and Radioactivity of the Areas Surrounding Wadi Um Sidra and Wadi Um Asmer, North Eastern Desert, Egypt. Ph.D. Thesis, Fac. Sci., Ain Shams Univ., 358.

Moghazi, A.M., 1994. Geochemical and radiogenic isotope studies of some basement rocks at the Kid area, southeastern Sinai, Egypt. Unpublished Ph.D. Thesis, Alexandria Univ., Egypt, 377.

Moghazi, A.M., F.H. Mohamed, and S. Kanisawa, 1999. Geochemical and petrological evidence of calc-alkaline and A-type magmatism in the Homrit Waggat and El-Yatima areas of eastern Egypt. J. Afr. Earth Sci., 29: 535-549.

Raslan, M.F., 1996. Mineralogical and beneficiation studies for some radioactive granites along Wadi Balih, North Easter Desert, Egypt. M.Sc. Thesis, Fac. Sci., Cairo Univ., 183.

Raslan, M.F., 2004. On the Distinction between Uranophane and Beta-uranophane from Some Uraniferous Granitoids in the Eastern Desert of Egypt. In Seventh International Conference on the Geology of the Arab World, Cairo Univ. C, 45-52.

Rogers, J.J.W., and J.A.S. Adams, 1969. Thorium-Uranium. In: K. H. Wedepohl (Ed.), Handbook of Geochemistry. Berlin, Springer Verlag, 2(3), Chap. 90\&92.

Rogers, J.W., and J.K. Greenberg, 1981. Trace elements in continental margin magmatism: part 111, Alkali-granites and their relationship to cratonization: Summary. Geol. Soc. Am. Bull., 92: 6-9.

Rogers, J.W., and J.K. Greenberg, 1983. Summary of recent work on Egyptian younger granites. Ann. Geol. Surv. Egypt XII, 185- 191.

Roz, M.E., 2001. Geology and uranium potentialities in Gabal Abu Harba environs, North Eastern Desert, Egypt. Ph.D. Thesis, Fac. Sci., Cairo Univ., 264.

Schmid, R. 1981. Descriptive nomenclature and classification of pyroclastic deposits and fragments. Geol. Rundsch, 70: 794-799.

Stein, M., and S. Goldstein, 1996. From plume head to continental lithosphere in the Arabian- Nubian Shield. Nature, 382: 773-778. 
Stern, R.J., 1994. Arc assembly and continental collision in the Neoproterozoic East African Orogen: implications for the consolidation of Gondwanaland. Annual Reviews in Earth and Planetary Sciences, 22: 319-351.

Stern, R.J., 2002. Crustal evolution in the East African Orogen: a neodymium isotopic perspective. J. Afr. Earth Sci., 34: 109-117.

Stohl, F.V. and D.K. Smith 1981. The crystal chemistry of the uranyl silicate minerals. American Mineralogist, 66: 610-625.

Tuttle, O.F., and N.L. Bowen, 1958. Origin of granite in the light of experimental studies in the system $\mathrm{NaAlSi}_{3} \mathrm{O}_{8}-\mathrm{SiO}_{2}-\mathrm{H}_{2} \mathrm{O}$. Geol. Soc. Am. Mem., 74: 153. 